\title{
Transitional rock glaciers at sea-level in Northern Norway
}

\author{
Karianne S. Lilleøren ${ }^{1}$, Bernd Etzelmüller ${ }^{1}$, Line Rouyet ${ }^{2}$, Trond Eiken ${ }^{1}$, Christin Hilbich ${ }^{3}$ \\ ${ }^{1}$ Department of Geosciences, University of Oslo, Oslo, N-0316, Norway \\ ${ }^{2}$ NORCE Norwegian Research Centre AS, Tromsø, N-9294, Norway \\ $5{ }^{3}$ Department of Geosciences, University of Fribourg, Fribourg, CH-1700, Switzerland
}

Correspondence to: Karianne S. Lilleøren (k.s.lilleoren@geo.uio.no)

\begin{abstract}
Rock glaciers are geomorphological expressions of permafrost. Close to sea level in northernmost Norway, in the sub-Arctic Nordkinn peninsula, we have observed several rock glaciers that appear to be active now or were active in the recent past.
\end{abstract}

Active rock glaciers at this elevation have never before been described in Fennoscandia, and they should be outside of the climatic limits of present-day permafrost according to models.

In this study, we have investigated whether or not these rock glaciers are active under the current climate situation. We made detailed geomorphological maps of three rock glacier areas in Nordkinn (Ivarsfjorden, Store Skogfjorden, and Lille Skogfjorden), and investigated the regional ground dynamics using Synthetic Aperture Radar Interferometry (InSAR). One of

15 the rock glaciers, namely the Ivarsfjorden rock glacier, was investigated in more detail by combining observations of vertical and horizontal changes from optical images acquired by airborne and terrestrial sensors and terrestrial laser scans (TLS). The subsurface of the same rock glacier was investigated using a combination of Electrical Resistivity Tomography (ERT) and Refraction Seismic Tomography (RST). We also measured ground surface temperatures between 2016 and 2020.

We mapped the rock glaciers in the innermost parts of Store and Lille Skogfjorden as relict, while the more active ones are in the mouths of both fjords, fed by active talus in the upslopes. Several of the rock glaciers cross over both the Younger Dryas shoreline ( $25 \mathrm{~m}$ a.s.1.), and the Tapes shoreline at $13 \mathrm{~m}$ a.s.l. Both InSAR and optical remote sensing observations reveal low yearly movement rates $\left(\mathrm{mm}-\mathrm{cm} \mathrm{yr}^{-1}\right)$. The ERT and RST suggest that there are no longer permafrost and ground ice in the rock glacier, while temperature observations in the front slope indicate freezing conditions also in summer. Based on the in-situ temperature measurements and the interpolated regional temperature data, we show that the MAAT of the region has raised by $2{ }^{\circ} \mathrm{C}$ since the late $19^{\text {th }}$ century to about $1.5^{\circ} \mathrm{C}$ in the last decade. MAATs below $0{ }^{\circ} \mathrm{C} 100$ 150 years ago suggest that the rock glaciers may have been active at the end of the Little Ice Age (LIA).

These combined results indicate that the Nordkinn rock glaciers are transitioning from active to relict stages. The study shows that transitional rock glaciers are still affected by creep, rock falls, snow avalanches, etc., and are not entirely dynamically dead features. Our contrasting results concerning permafrost presence and rock glacier activity show the importance of a multi-methodical approach when investigating slope processes in the edge zones of permafrost influence. 


\section{Introduction}

Permafrost, defined as ground with temperatures remaining at or below $0^{\circ} \mathrm{C}$ at least two consecutive years (Van Everdingen, 1998), is widespread in mountain areas. The distribution of mountain permafrost is governed by air temperature and snow cover, which is strongly modulated by topography in high-relief settings (Harris and Vonder Muhll, 2001; Gisnås et al., 2017;

35 Harris and Corte, 1992). The ground thermal regime in general influences gravitational processes, like mass wasting, and is thus an important factor for landscape evolution (Berthling, 2011; Egholm et al., 2013; Hales and Roering, 2009; Hales and Roering, 2007).

Some landforms directly indicate the presence of permafrost, e.g. palsas, peat plateaus and rock glaciers. While palsas form in topographic depressions occupied by mires, rock glaciers are located in sloping terrain with talus, avalanche debris, or morainic deposits. Rock glaciers form when ice-cemented ground starts to creep because of the ice's plasticity and gravity (King, 1986; Delaloye and Lambiel, 2005; Farbrot et al., 2007; Haeberli, 1985; Berthling, 2011). In 2011, a Norwegian rock glacier inventory of 307 landforms was published (Lilleøren and Etzelmüller, 2011), mainly based on the digital aerial photos available at that time. The quite few examples of mapped rock glaciers close to sea level are situated in areas that were deglaciated before the Younger Dryas (YD), and where climatic conditions favoured permafrost development outside the

45 Weichselian ice margin during the deglaciation (Andersen, 1981; Sollid et al., 1973). In Norway, clusters of rock glaciers at sea level are found in the Vesterålen-Andøya area in Nordland, the Kåfjord-Lyngen area in Troms and the north-eastern part of Finnmark towards the Barents Sea (Sollid and Sørbel, 1992) (fig. 1). In the 2011 rock glacier inventory, we interpreted the level of activity based on the available aerial photos at that time, and categorized the landforms as either 'active' (steep front slopes, deep ridges and furrows indicating movement, creep structures), 'inactive' (less clear signs of movement, but with a "fresh" appearance), and 'relict' (extensive vegetation cover, thermokarst structures, no signs of movement). In this study, we have had access to kinematic data of the land surface, and we have therefore used the recent categorization of an International Permafrost Association (IPA) action group on rock glaciers kinematics. Here, 'active' rock glaciers move at more than $0.1 \mathrm{~m}$ $\mathrm{yr}^{-1}$, 'transitional' at between 0.01 and $0.1 \mathrm{~m} \mathrm{yr}^{-1}$ and 'relict' at less than $0.01 \mathrm{~m} \mathrm{yr}^{-1}$ (IPA, 2020). In this study, 'active' and 'transitional' have sometimes been grouped to 'intact' landforms. However, the latter definition does not include any reference to the ice content of the rock glacier interior, only its movement.

While the coastal rock glaciers in Nordland and in the Lyngen area of Troms probably are relict, partly overgrown with vegetation and with relatively smooth topography, the rock glacier clusters in northernmost Finnmark show clear signs of recent activity with steep fronts, ridges and furrows. If these rock glaciers are active, this would influence our understanding of permafrost distribution in the northernmost coastal areas of Norway. In order to investigate the activity and history of these landforms, we launched a mapping and monitoring program, where we (1) produced detailed geomorphological maps for three focus areas (Ivarsfjorden, Store Skogfjorden and Lille Skogfjorden), (2) analysed mean annual surface velocity of all rock glaciers in the area based on Sentinel-1 Synthetic Aperture Radar Interferometry, and (3) monitored one rock glacier (Ivarsfjord rock glacier, north of Hopsfjorden; $71^{\circ} \mathrm{N}, 28^{\circ} \mathrm{E}$; fig. 1), by combining different techniques to document internal structure 
(geophysical surveys), thermal regime (near-surface temperature data loggers and thermal camera) and displacement rates comprehensive overview of the ground thermal state and rock glacier dynamics in the area. Thus, this study provides new insights about former and present permafrost distribution in this sub-arctic environment, and the morpho-genetic development of rock glaciers after the deglaciation.

\section{Setting}

Finnmark is dominated by wide fjords in the coastal areas (west, north and east), and large plateaus in the south (Finnmarksvidda). Between the larger fjords towards north, the landscape of the peninsulas is dominated by steep mountain slopes towards the sea and flat plateaus in the interior areas, normally with elevations below $600 \mathrm{~m}$ a.s.l. These plateaus are dominated by exposed bedrock or in situ weathered material, and in some areas coarse-grained till.

The bedrock of the Nordkinn peninsula north of Hopsfjorden generally consists of siliclastic, folded metasedimentary rocks from late Mesoproterozoic to early Neoproterozoic (fig. 1d). These rocks are parts of the Kalak Nappe Complex, included in the Caledonian fold belt (Schilling et al., 2014). The bedrock in Ivarsfjorden, Store Skogfjorden and Lille Skogfjorden consists of sandstones and phyllites (NGU 2008). The area is dominated by phyllitic schists and shales, with quarzitic sandstones as southwest-to-northeast belts in the landscape.

During the Pleistocene, Finnmark was repeatedly glaciated, last by the Fennoscandian Ice Sheet (FIS), where ice streams flowing west and north coalesced with the Barents Sea Ice Sheet (BSIS) (Boulton et al., 2001; Dowdeswell and Siegert, 1999; Shackleton et al., 2018; Ottesen et al., 2005). The northern areas, including Nordkinn, was early deglaciated, appr. 1415 cal kyr BP (Romundset et al., 2011). In lake sediment records, Romundset et al. (2011) find indications of an abrupt regression that occurred between 10.5 and $10 \mathrm{cal}$ kyr BP. In the following period between 10 and $5 \mathrm{cal} \mathrm{kyr}$ BP, a transgression occurred, while during the last $5 \mathrm{kyr}$, the relative sea level has fallen by $10 \mathrm{~m}$. A significant uplift of the coast of Finnmark happened when the Barents Sea ice sheet disintegrated, which occurred prior to the main Holocene uplift (at 17-15 cal kyr BP, Winsborrow et al., 2010). Due to the disappearance of the Barents Sea ice sheet, the shoreline gradients in outer part of Finnmark are about three times lower when compared to similar areas of the Norwegian coast and the marine limit was reached as early as ca $14.6 \mathrm{cal}$ kyr BP (Romundset et al., 2011).

The climate of Finnmark varies between a relatively mild, wet maritime climate at the coast, to a dry continental climate in the interior ((MAAT from -2 (coast) to $-4{ }^{\circ} \mathrm{C}$ (interior); Vikhamar-Schuler et al., 2010). The mean annual precipitation (MAP) ranges from $400 \mathrm{~mm}$ at Finnmarksvidda to slightly above $1000 \mathrm{~mm}$ at the coast, and the snow depth increases from $50 \mathrm{~cm}$ in the continental areas to $200 \mathrm{~cm}$ at the coast (Saloranta, 2012b).

The present lower limit of permafrost in continental parts of Finnmark is situated at 500-600 m a.s.l (Farbrot et al., 2013,

95 Gisnås et al 2017), while it increases to $1000 \mathrm{~m}$ a.s.l. towards the coastal areas (Farbrot et al., 2008). The snow distribution 
and elevation have a major influence of the permafrost distribution, as discussed in several studies modelling mountain permafrost in Norway (Farbrot et al., 2013; Obu et al., 2018; Gisnås et al., 2017). The Nordkinn peninsula is at the edge of the modelled regional permafrost extent.

The rock glaciers in Finnmark have previously all been interpreted as relict landforms (Lilleøren and Etzelmüller, 2011; Lilleøren et al., 2013). Similarly, the large number of frost polygons in Eastern Finnmark are interpreted as relict (Svensson, 1962, 1992; Malmström and Palmér, 1984). These frost-fissures are located both at raised beaches, up to about 100 m a.s.l., and in blockfields at higher elevations (Svensson, 1986, 1962; Malmström and Palmér, 1984; Fjellanger et al., 2006). When excavating relict polygons on raised beaches, ice-wedge casts have been identified, which is a clear indication of former permafrost (Svensson, 1986).

\section{Methods and data processing}

In this study we have focused on three areas, Ivarsfjorden (north of Hopsfjorden), Store Skogfjorden and Lille Skogfjorden (both south of Hopsfjorden, fig. 1). All three areas are tributary fjords to the main Hopsfjorden.

\section{$110 \quad 3.1$ Regional geomorphological and kinematical mapping}

The main objective of the geomorphological mapping was to identify rock glaciers and other related landforms with their main surface structures, and how they relate to especially relict raised shorelines in the area. For this work we used a high-resolution LiDAR-based Digital Elevation Model (0.25-0.5 m resolution), in combination with aerial orthophotos (1529C10_1529C12 (1975), 7594B7_7594B9 (1982), 11418C10_11418C12 (1992); Norwegian Mapping Authorities) within a Geographical

115 Information System (GIS) environment (ArcMap (C ESRI)).

For the documentation of rock glacier kinematics, we analysed ground velocity maps processed with Synthetic Aperture Radar Interferometry (InSAR) based on 2015-2020 Sentinel-1 Interferometric Wide Swath images (tracks 51 and 124). We combined two datasets processed with different InSAR techniques to take advantage of complementary detection capabilities. InSAR measurements are available through the InSAR Norway ground motion mapping service (www.insar.ngu.no; Dehls et al., 2019). The dataset is based on a Persistent Scatterer Interferometry (PSI) technique (Ferretti et al., 2001). InSAR Norway covers the whole country with a ground resolution of approximately $5 \times 20$ meters ( 5 meters in the east-west and 20 meters in the north-south direction). The dataset is typically designed for $\mathrm{mm} \mathrm{yr}^{-1}$ to $\mathrm{cm} \mathrm{yr}^{-1} \mathrm{ground}$ velocities, originally developed for investigating movement on infrastructure and large rock slope instabilities (Vick et al., 2020). PSI may fail over fast and non-linear moving areas. To complement InSAR Norway in these areas, additional velocity maps have been processed by averaging exclusively image pairs with a short temporal interval ( 6 to 48 days). The technique, so called InSAR stacking (Sandwell and Price, 1998), is less robust for low velocities due to remaining atmospheric effects, 
but allows for documenting high velocities following the methodology detailed in Rouyet et al. (2021). The spatial resolution of the final product is lower than PSI (40 x $40 \mathrm{~m}$ ). For rock glaciers located on west-facing slopes, we used exclusively InSAR data based on descending radar geometry. The final composite map is used to provide a general overview of the ground velocities in the study area and categorize the rock glacier kinematics (order of magnitude). The InSAR values correspond to mean annual ground velocities corresponding to sensor-to-ground distance change along the radar line-of-sight (LOS). As the view angle is mostly aligned with the slope orientation and that the kinematic analysis remains semi-quantitative, no projection has been applied for this study.

\subsection{Ivarsfjorden rock glacier}

135 Three series of aerial photos were used to generate DEMs and orthophotos (1975, 1982 and 1992; Norwegian Mapping Authorities). We used the photogrammetric software suite "ImageStation" for the processing of historical data (Hexagon Geospatial Company). From 2016 to 2019, we collected annual aerial photos from the rock glacier and its close surroundings, using a Camflight C8 Rotor Wing Unmanned Air Vehicle (UAV). The camera used was Nikon Coolpix A, with a resolution of 4928 x 3264 pixels, a focal length of $18.5 \mathrm{~mm}$ (Sundheim \& Andresen 2016), and a resulting ground sample distance (GSD) of ca. $3.5 \mathrm{~cm}$. The images retrieved by drones were processed using the AGISOFT Photoscan software, georeferenced and ortophotos made with $5 \mathrm{~cm}$ resolution. 2019 photos were not suitable for further analyses, and discarded (the GNSS reference point had been destroyed and ground control similar to previous years could not be established). We also acquired terrestrial laser scans (TLS) in the years 2017-20, using a Riegl VZ1000 terrestrial scanner, covering most of the surface. The DEMs generated from the TLS have a ground resolution of 2-15 $\mathrm{cm}$ and an accuracy of 2-4 $\mathrm{cm}$ (Table 1).

The multi-temporal DEMs were subsequently analysed for vertical changes over the rock glacier body, by subtracting the newest from the oldest DEMs between selected periods. For horizontal displacement analysis of the rock glacier, we used the Correlation Image Analysis Software (CIAS; Kääb and Vollmer, 2000; Heid and Kääb, 2012). The software uses the orthophotos to recognize objects such as large stones and blocks on all images, and then calculates the coordinate displacements of the objects. We analysed surface displacements between 7 image pairs between 1975 and 2018.

Electrical Resistivity Tomography (ERT) and Refraction Seismic Tomography (RST) were carried out during the field seasons of 2017, 2018 and 2019 (fig. 1). ERT documents the electrical resistivity distribution of the subsurface by injecting a current between two electrodes, and measuring the resulting electrical potential differences between two other electrodes along the profile. The depth of investigation depends on the distances between the current electrodes employed along the profile and the profile length, with larger distance giving greater penetration. Liquid water in the ground (soil moisture, ground water) causes low electrical resistivity values, whereas the resistivity of the same material can increase strongly under frozen conditions (Hauck and Kneisel, 2008). As ice acts as an electrical insulator, the resistivity increases with increasing ice content, and high electrical resistivities can indicate frozen conditions (but also dry porous material, as air is also an electrical insulator). Seismic tomography documents the P-wave velocity distribution along the profile by emitting seismic waves at several shot points and measuring the resulting travel times between source (hammer) and receiver 
(geophones). The P-wave velocity is a function of the elastic properties of the ground material, and the analysis of the seismic travel times provides structural information about the different subsurface layers. Because of their complementary nature, ERT and seismic refraction are often combined for permafrost applications to distinguish between ground ice (high resistivity and medium P-wave velocities), liquid water (low resistivity and P-wave velocities) and air (high resistivity, low P-wave velocities; Hilbich, 2010). Further, the obtained specific resistivity and P-wave velocity distributions can be used as input variables in a petrophysical model approach to quantify the volumetric fractions of the four phases ice, water, air and rock in the ground under the assumption of a site-specific porosity distribution (Hauck et al. 2011). This model approach has previously successfully been applied to various permafrost occurrences (e.g. Pellet et al. 2016, Mewes et al. 2017, Halla et al. 2020).

For ERT, we used an ABEM Terrameter LT, with 2 or 4 cables, and an electrode spacing of $2 \mathrm{~m}$. For results' inversion, we used the Res2DINV software (Aarhus Geosoftware; Loke, 2018; Loke and Barker, 1996b, a). For RST, we had a Geode hammer seismograph (C Geometrics) with 24 geophones. We used a geophone spacing of $4 \mathrm{~m}$. In 2017, we measured two short separate ERT profiles ( $80 \mathrm{~m}, 2$ cables), one close to the centre of the rock glacier and the other at the front crossing into the rock glacier forefield ('ERT 2017', fig. 1d). In 2018, we measured the full rock glacier length by ERT, a total of $480 \mathrm{~m}$ ('ERT 2018', fig. 1d), while in 2019 we did seismic surveys along two major profiles ('RST' in fig. 1d).

In 2015, we employed 15 miniature data loggers (MTD) within and outside the Ivarsfjord rock glacier boundary (fig. 1d). We used MAXIM iButtons, with a resolution of $\pm 0.25^{\circ} \mathrm{C}$, and placed them in voids close to the surface. We received fullyear temperature data from most of the loggers between 2015 and 2020. To identify air circulation in the rock glacier, we systematically investigated the rock glacier front using a thermal camera, measuring infrared radiation (FLIR; forward-looking infrared).

For comparison and extrapolation of the temperature series, we used gridded climate data (daily air temperatures and precipitation) available for all of Norway since 1957 at a ground resolution of $1 \mathrm{~km}$. This dataset, in the following called "SeNorge", is established by interpolation between meteorological stations (Lussana et al., 2018; Saloranta, 2012a), and is updated daily. To evaluate temperature development since the end of the Little Ice Age (LIA) at the study sites, we followed two strategies. First, we adapted the SeNorge data series back to 1957 at Ivarsfjorden, and made regression analyses between each of the Ivarsfjorden MTD ground surface temperature and the SeNorge daily air temperature series $\left(\mathrm{R}^{2}>0.8\right)$. The difference between ground surface and air temperature occurs especially in winter because of surface snow cover. Second, we applied a linear regression between the SeNorge data and the observed temperatures at Vardø radio meteorological station $\left(\mathrm{R}^{2}\right.$ $=0.96$ ), where continuous observations of air temperatures exist since 1868 . 


\section{Results}

\subsection{Hopsfjorden Quaternary geology and geomorphology}

In three of the tributary fjords to Hopsfjorden (Ivarsfjorden, Store Skogfjorden and Lille Skogfjorden (fig. 1c), a series of rock glaciers are situated at low elevations, partly crossing old raised shorelines (fig. 2). Mapping and field observations in the fjord settings distinguished between rock glaciers appearing with and without visible signs of movement ('intact' and 'relict' rock glaciers, respectively). Relict rock glaciers are situated in the southern and innermost parts of the fjords, and the intact landforms are situated towards north and close to the mouths of the fjords (figs. $2 b$ and $2 c$ ). There are several differences between these inner and outer systems, both in terms of geomorphology and geology. The intact rock glaciers are located below steep and high headwalls, where rockfall debris dominate, and blocky talus cones are common. The lithology of these rock glaciers are quarzitic sandstones. The rock glaciers interpreted as relict are located in gentler slopes with lower headwalls, and affected by both rockslide debris, soil creep and mudslides. These rock glaciers consist of a mix of phyllite and more coarse-grained debris. The transition from intact to relict rock glaciers has a quite distinct spatial distribution, where the southern parts of Store and Lille Skogfjorden exclusively contain relict rock glaciers, while the northern parts have both relict and intact rock glaciers. However, all observed rock glaciers in the area, whether they are intact or relict, are found in the northwest-facing eroded slopes of the sandstone belts trapped between the phyllites. The slopes have a dominantly western exposure and elevations between 20 and $100 \mathrm{~m}$ a.s.l. (fig. 2).

The marine sediments in the mapped areas reach an elevation of $60 \mathrm{~m}$ a.s.l. in Hopsfjorden. The thickness is unknown, and the surface is characterized by multiple old shorelines (fig. 2). The uppermost marine sediments were formed during the first deglaciation and the following regression of the sea level that occurred after 15k cal yr (Romundset et al., 2011). The later Holocene transgression is visible as a large, distinct but discontinuous ridge, at about $13 \mathrm{~m}$ a.s.l.

An interesting observation in Store Skogfjorden was a rockslide that occurred at some point between 2008 and 2018, when we have aerial photos (fig. 3). This rockslide was released in the sandstone zone, had a short transport length (up to 200 $\mathrm{m}$ ), covered an area of ca. $0.08 \mathrm{~km}^{2}$ and deposited a volume of ca. $1200 \mathrm{~m}^{3}$ (assuming an average thickness $\mathrm{h} \approx 15 \mathrm{~m}$ ). The deposit is shaped as a lobe with a steep and distinct front slope, showing surface structures that could be interpreted as creep features, and thus be misinterpreted as a rock glacier.

Large fields of semi-regular networks of linear depressions are observed on the blockfield-covered mountains between Lille and Store Skogfjorden and in the Sandfjellet mountain, east of the Ivarsfjord rock glacier (fig. 2a). Similar patterns have been observed and described other areas of Finnmark (e.g. Fjellanger et al., 2006). Excavations in an interception of two such furrows at Buhkkačearru (450 m asl), Varanger peninsula (east of our study area), revealed a 1-1.5 m deep feature interpreted as a relict ice-wedge ((Malmström and Palmér, 1984)). Malmström and Palmér (1984) found no evidence of recent permafrost during their fieldwork. 


\subsection{Regional InSAR-based kinematic analysis}

From the regional InSAR ground velocity analysis, clear kinematic patterns are identified. In general, especially the upper talus parts of the rock glaciers are generally moving with significant ground displacement rates between $3 \mathrm{~cm} \mathrm{yr}^{-1}$ and $\sim 30 \mathrm{~cm}$ $\mathrm{yr}^{-1}$ (fig. 4A). The flatter lobate parts between the feeding zones and the fronts display small to negligible velocities generally below 1-3 $\mathrm{cm} \mathrm{yr}^{-1}$ (fig. 4). The rockslide deposit referred to in the previous section (fig. 3A) also shows considerable movement of above $10 \mathrm{~cm} \mathrm{yr}^{-1}$. In the regional survey, the Ivarsfjorden rock glacier shows the same displacement pattern as the rock glaciers in Store and Lille Skogsfjord. InSAR velocity maps are used to categorize the order of magnitude of the rock glacier creep rates (fig. 4B), according to the new recommendations of the International Permafrost Association Action Group "Rock glacier inventories and kinematics" (IPA, 2020). Based on the geomorphology and the InSAR kinematics, 44 rock units are identified and indicatively delineated (fig. 4B). A kinematical attribute is associated to each unit. Most units (27) have slow

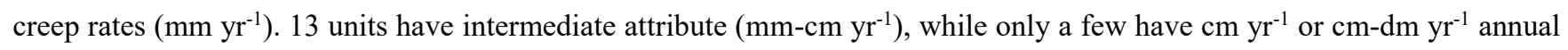
rate (4).

\subsection{Ivarsfjorden rock glacier monitoring and analysis}

235 We estimated the lowest accuracy for any of the DEMs derived from the orthophotos to $\pm 0.41 \mathrm{~m}$, thus all difference values below $0.5 \mathrm{~m}$ were discarded (Table 1). The elevation differences between the various DEMs on the rock glacier are primarily in the range of $\pm 2 \mathrm{~m}$, which correspond to vertical changes of 0-30 $\mathrm{cm} \mathrm{yr}^{-1}$ (Table 2, fig. 5). The most persistent changes over time are observed at the talus cones in the upper parts, in the front slopes and in some lobes in the centre of the rock glacier (fig. 5).

When comparing the elevation differences between the various periods, some patterns can be highlighted. In all time periods the talus cones increased in elevation, i.e. accumulated mass, in the upper part of the rock glacier at rates of 5-20 cm $\mathrm{yr}^{-1}$. The 1982-2017 and 1992-2017 periods also show a mass accumulation at the front of the rock glacier at 6-10 $\mathrm{cm} \mathrm{yr}^{-1}$ (Fig. A1, in appendix), where the largest rate of increase occurs in the 1992-2017 period (Table 2).

The elevation differences between the 2016 and 2017 UAV DEMs were larger than the previous years, in general in the range of $\pm 5 \mathrm{~cm} \mathrm{yr}^{-1}$, mostly due to surface raise (fig. $5 \mathrm{c}$ ).

We also compared TLS' from 2017 and 2020 which revealed lower yearly rates than between 2016 and 2017, but generally a lowering of the surface of mostly between 0 and $10 \mathrm{~cm} \mathrm{yr}^{-1}$.

The analysis of block movement on the rock glacier revealed significant horizontal velocities of generally around 0.5 to $1 \mathrm{~cm} \mathrm{yr}^{-1}$ between 1975 and 2017 (fig. 5). Maximum velocities were measured in the northern area of the rock glacier, close to the talus/avalanche cone, with values between 2 and $3 \mathrm{~cm} \mathrm{yr}^{-1}$. Comparison of drone-based orthophotos between 2016 and 2017 shows a more evenly distributed pattern, with higher displacement rates than the previous time periods. The velocities correspond well with the regional InSAR observation shown in fig. 4. 
The long ERT profile (2018) provides measurements from the rock glacier forefield and into the upper talus cones feeding the rock glacier (fig. 6). The resistivity profiles show a distinct transition from the area outside the rock glacier $(<5$ $\mathrm{k} \Omega \mathrm{m}$ ) and the rock glacier body ( $>10 \mathrm{k} \Omega \mathrm{m}$ ), with maximum values of $>100 \mathrm{k} \Omega \mathrm{m}$. High resistivity values in such blocky material are normally related to the fact that pores between the blocks are either filled with air or ice. This system can be interpreted as ice and frozen ground below a thawed active layer.

The highest velocities recorded in the seismic refraction profiles were just above $1500 \mathrm{~m} \mathrm{~s}^{-1}$ at the lowest depth of penetration. The majority of recorded velocities was in the range of 500 to $1000 \mathrm{~m} \mathrm{~s}^{-1}$, which are the typical velocities expected from unconsolidated debris with large air pockets (fig. 6). In the case of substantial ice content in the pores, we would expect velocities well above $2000 \mathrm{~m} \mathrm{~s}^{-1}$ and for pure ice above $3000 \mathrm{~m} \mathrm{~s}^{-1}$ (Hauck et al., 2011). Frozen rocks typically give a seismic velocity of $3500-4000 \mathrm{~m} \mathrm{~s}^{-1}$. The wave velocity increases with depth, and this is probably due to debris compaction.

In summary, the results of the two geophysical methods seem to contradict each other: while the ERT data indicate frozen conditions (high resistivities), the RST data do not detect any probability for ground ice. This paradox has already been observed in other situations (e.g. talus slopes), where ground ice can be expected, but with limited volumetric ice content, which does not sufficiently affect the seismic p-wave velocity. We therefore interpret the data in that way, that the presence of ground ice cannot be excluded from the interpretation of both geophysical methods, but that the RST data strongly suggest a small overall ice content (little saturation of the available pore space).

The measured ground surface temperatures show mean annual values between 1.8 and $3.6^{\circ} \mathrm{C}$ from 2015 to 2020 (fig. 1). The lowest temperatures were recorded (1) in the upper slope of the rock glacier $\left(2.5^{\circ} \mathrm{C}\right.$ in average for 3 loggers), (2) in the northern front edge of the rock glacier where we also observed gusts of cold air in summer $\left(2.5^{\circ} \mathrm{C}\right)$, and (3) in one of the creeks escaping the rock glacier $\left(2.6^{\circ} \mathrm{C}\right.$ ). The modelled SeNorge air temperature of Ivarsfjorden rock glacier (grid cell mean elevation $116 \mathrm{~m}$ a.s.l.) of the same time period is $1.7^{\circ} \mathrm{C}$, slightly lower than the measured mean annual ground surface temperatures.

Table 3 shows the SeNorge mean air temperatures for each decade between 1870 and 2019, for the grid cell that covers Ivarsfjorden rock glacier (grid cell mean $116 \mathrm{~m}$ asl) and for the grid cell adjacent to the East covering the plateau mountain Sandfjellet (grid cell mean $338 \mathrm{~m}$ asl). For the decades prior to 1957 we have used the relationship between Vardø radio and SeNorge. There is a general increase in temperatures from ca. -0.6 to $0.5{ }^{\circ} \mathrm{C}$ from the late 1800 s to ca. 2000 , and further from 0.5 to $1.6^{\circ} \mathrm{C}$ since 2000 until now.

We complemented our thermal analyses with infrared pictures taken in the front slope of the rock glacier (Fig. 7). On an unusual warm day in September $2018\left(>20^{\circ} \mathrm{C}\right)$, it was possible to feel gusts of cold air escaping the lowest parts of the rock glacier, and the thermal camera showed areas of $0{ }^{\circ} \mathrm{C}$ in parts of the front slope network of blocks and air (fig. 7). 


\section{Discussion}

\subsection{Rock glaciers in Hopsfjorden - active today?}

One of the major aims of this study was to evaluate the activity of the rock glaciers in the area. If active, this would imply permafrost conditions at sea level in northern Norway, following the rock glacier definitions in Haeberli (1985), Barsch (1992) and Berthling (2011). Both current climate information and permafrost models suggest that these coast-near areas are permafrost-free. However, landforms such as palsas and peat plateaus are found in mires developed close to sea-level, especially in glacio-fluvial delta deposits, all along the northern coasts of Finnmark (Sollid and Sørbel, 1998; Borge et al., 2017; Meier, 1987; Kjellman et al., 2018), which clearly demonstrate sporadic permafrost in these locations. Both the peat cover associated with organic material and the blocky talus material normally depress and delay warming of ground temperatures, and thus both palsas and rock glaciers can be found below the regional lower limit of mountain permafrost, such as in high latitude mountain areas in e.g. Scandinavia and Iceland (King, 1986, Delaloye and Lambiel, 2005, Farbrot et al., 2007a). Thus, an active rock glacier in a permafrost environment should move, and the movement should be related to the deformation of internal ice bodies (Berthling, 2011).

Based on the yearly displacement rates from optical remote sensing in the Ivarsfjord case study and from InSAR at the regional scale, we see that there is a systematic pattern in the displacement of the slopes inhabited by rock glaciers. Most of them have the maximum displacement values in the upper slopes and the frontal slopes, while only some rock glaciers have displacement rates of more than $3 \mathrm{~cm} \mathrm{yr}^{-1}$ over their whole surface. Although the absolute values of the displacement may differ slightly between the methods due to different time periods, resolutions and measurement dimensionality, the overall

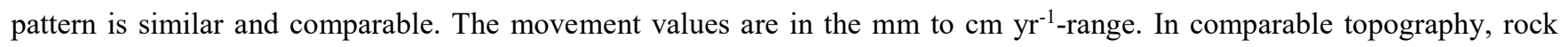
glaciers ending on strandflats in western Svalbard had velocities around 1-5 $\mathrm{cm} \mathrm{yr}^{-1}$ according to GPS measurements (Berthling et al., 1998; Farbrot et al., 2005), and InSAR (Bertone et al., 2020). Svalbard lies in the continuous permafrost zone, and the low movement rates for the landforms ending on strandflats are partly attributed to low-inclined slopes (Berthling et al., 1998). Therefore, low displacement rates do not necessarily exclude active permafrost creep.

The ground resistivity measurements on Ivarsfjorden rock glacier showed resistivity values above $50 \mathrm{k} \Omega \mathrm{m}$, increasing up-slope, which would indicate possible high ice content. However, the RST surveys revealed velocities in the zone of the resistivity maximum far below what to be expected of massive ice, with values close to or below $1000 \mathrm{~m} \mathrm{~s}^{-1}$, which rather would imply a porous air-filled medium such as blocky talus deposits (Hauck et al., 2011). Deeper in the ground, the velocities reach up to $2000 \mathrm{~m} \mathrm{~s}^{-1}$, which would be more probable for permafrost, but can also be interpreted compacted talus deposits (the depth perfectly agrees with the depth of the third layer in the ERT). This clearly weakens the permafrost presence hypothesis. An uncertainty is that the two methods were utilized in two consecutive years (ERT in 2018 and RST in 2019),

315 which could imply that the ground thermal regime was different during the two investigations. Temporary ice layers could have formed and resulted in the high resistivity layers measured in 2018. However, 2018 was a summer warmer than average and 2019 was colder than average. We therefore consider that this alternative is unlikely. 
The GST monitoring showed clearly $>0{ }^{\circ} \mathrm{C}$ annual average temperatures at all places, with a temperature range of

ca. $2{ }^{\circ} \mathrm{C}$. Such variation over short distances are commonly observed in mountainous areas (Gubler et al., 2011), and is attributed to snow variations (Gisnås et al., 2016). The GST observations contradict the existence of extensive permafrost in the rock glacier. However, the thermal camera recorded negative summer temperatures in the front slope of the Ivarsfjord rock glacier, most likely a sign of a chimney effect causing the dense, cold air to sink through the openwork blocks of the rock glacier (e.g. Lambiel and Pieracci, 2008; Wicky and Hauck, 2017; Kenner et al., 2017; Yuki et al., 2003). We never observed ground ice during fieldwork. However, the present cold air flow indicates the existence of at least minor ice bodies in the rock glacier.

In summary, the thermal camera imagery and the ERT measurements suggest favourable conditions for permafrost occurrence, but the results based on RST and in-situ temperature loggers tend to contradict this conclusion. The chimney ventilation effect probably cools the ground in summer, and also indicates that there is an open subsurface network to support air flow. Our measurements were generally performed at the end of the melting season, in late summer and early fall, thus we did not observe warm air escaping from the upper slopes of the rock glacier during winter. There might also be an ice core present at one or several locations in the ground, that grows in winter and that mostly disappears during summer (Delaloye and Lambiel, 2005).

The deformation rates that are observed both from the InSAR and optical remote sensing analyses is therefore most probably not caused by permafrost creep, driven by massive deforming ice bodies, at least in most of the landforms with a similar movement pattern than Ivarsfjorden rock glacier. This is supported by the facts that most movement is observed in the talus feeding the rock glaciers, and may be attributed to other processes than ice deformation such as avalanches, rock falls and solifluction.

\subsection{Development of the Hopsfjorden rock glaciers}

The observations from Hopsfjorden discussed above can be interpreted as landforms in transition from an active to a relict state in response to climate change and atmospheric warming. The landforms must have been formed during periods with cooler climate and a favourable topographic and geological setting.

The location and existence of the rock glaciers in Hopsfjorden are clearly controlled by the local geology, as they almost exclusively are found in the belts of quarzitic sandstones. The rock glaciers in this area all have a westerly aspect, which can be related to the foliation of the bedrock in the area. Considering the slope aspect, and hence solar insolation, there should not be any difference between the phyllite and the sandstone slopes; the difference is interpreted to be in the weathering products of the two dominating bedrock types. It is well known that phyllite-type bedrock is not a common source for rock glaciers (Haeberli et al., 2006; Ikeda and Matsuoka, 2006). Phyllites or similar schist types produce more fine-grained weathering material, which is frost-susceptible, and more prone to slow slope movement such as solifluction or episodic rapid events such like debris flows (Haeberli et al., 2006; Matsuoka and Ikeda, 2001). The higher competence of the quarzitic 
blockfields. The physical appearance of the rock glaciers are affected by how coarse the rock glacier material is, where blocky rock glaciers have sharp frontal edges and multiple ridges, while the pebbly or more fine-grained rock glaciers have subdued frontal slopes and often lack the ridge and furrow systems (Matsuoka and Ikeda, 2001; Ikeda and Matsuoka, 2006).

Rock glaciers develop over long time periods (millennia), fed by low magnitude and high frequency events below rock walls. However, certain types of rapid events such as snow avalanches (Humlum et al., 2007) or rockslides (Etzelmüller et al., 2020) may form similar-shaped landforms. The observed rockslide south of Store Skogfjorden (fig. 3) is interesting for understanding which processes dominate the build-up of scree in Norwegian slopes. The sandstones of the release zone favour production of large boulders, which is favourable to chimney effects and cooling of the ground in summer. This rockslide demonstrates that the slopes in the area are unstable due to fault zones, where the main lines of strike are subparallel to the length direction of all the tributary fjords of Hopsfjorden. Rock glaciers are defined as an accumulated mass of ice-cemented, but unconsolidated debris (Barsch, 1992; Berthling, 2011), but permafrost creep can also occur as secondary processes in all kinds of loose material deposited in slopes in cold climate areas. This landslide deposit could, if situated in a permafrost environment, develop into a rock glacier over time, such e.g. suggested for some large debris bodies in Iceland (Etzelmüller et al., 2020) or as a paraglacial response to deglaciation (Mccoll, 2012; Ballantyne, 2002). Therefore, the other rock glaciers in the same fjord system, situated along the same fault line, could also have developed from the deposits of one or more low frequent and high magnitude rockslide events.

Some of the rock glaciers cross several raised shorelines, for example one particular rock glacier at the mouth of Lille Skogfjorden (fig. 2c). This rock glacier must therefore have been active during and following the land uplift of the early Holocene. The most prominent shoreline located by this rock glacier might be the Tapes shoreline, which according to Sollid et al. (1973) is situated ca. $13 \mathrm{~m}$ a.s.l. This is consistent with our observations. The paraglacial relief of the slopes may itself have caused rock debris masses to form and further to creep in a permafrost environment (Mccoll, 2012; Ballantyne, 2002). The early deglaciation (14-15 cal kyr BP; Romundset et al., 2011) and no later glacier advances in the area left enough time for proper rock glacier accumulation over millennia, with probable stages of less or no activity during the Holocene, e.g. during the Early Holocene Thermal Maximum (HTM), and the later Roman, Medieval and Modern Warmings.

The rock glaciers may have been reactivated during colder time periods such as the Neoglaciation and the LIA. The area has warmed by about $2{ }^{\circ} \mathrm{C}$ between 1868 and present, and the same between 1957 and present (fig. 8). With an assumed MAAT of $1.6^{\circ} \mathrm{C}$ in the $2010-2019$ decade, the MAAT could have been just below $0{ }^{\circ} \mathrm{C}$ both in the middle of the last century and the end of the $19^{\text {th }}$ century. This temperature raise could have triggered a change from an environment where permafrost was present and stable to an environment with thaw and non-favourable conditions for permafrost. Landslides released prior 380 to the $20^{\text {th }}$ century could therefore develop into rock glaciers, while the permafrost presence is degrading under the current climate. 


\subsection{Finnmark rock glaciers: an analogy to Svalbard in a changing climate?}

Nordkinn rock glaciers differ from most other rock glaciers in mainland Norway by terminating close to sea level on a flat coastal plane, comparable to near-shore rock glaciers described from western and northern Svalbard (Berthling et al., 1998; Farbrot et al., 2005; Sollid and Sørbel, 1992; Liestøl, 1961), where rock glaciers creep from talus slopes onto the strandflat. Based on earlier studies, these Svalbard landforms were marked as moraine deposits on geomorphological maps, but Liestøl (1961) introduced the term "talus terraces" to footslope landforms "built of ice and rock debris from the slope above (...)" (Liestøl 1961, p. 102). Liestøl (1961) acknowledges that the "talus terraces" at numerous locations resemble rock glaciers, and would indeed fall into the present-day rock glacier definition. The rock glaciers in western Svalbard are creeping into the strandflat with relatively low velocities, mostly below $10 \mathrm{~cm} \mathrm{yr}^{-1}$ (Berthling et al., 1998; Isaksen et al., 2000), attributed to cold ice and low inclination as they run out over the strandflat (fig. 9). Despite difference of climate settings, both for the Hopsfjorden and western Svalbard rock glaciers, there is a zone of higher displacement rates observed in the talus directly above the rock glacier, i.e. at places where the slope angle starts decreasing.

For Svalbard, the air temperatures fluctuated strongly over the $20^{\text {th }}$ century (fig. 8), with an overall increasing trend of $+0.3{ }^{\circ} \mathrm{C} /$ decade for the Svalbard airport meteorological station (Nordli et al., 2014). Between 1971 and 2017, the temperature increased at the same meteorological station by $+1{ }^{\circ} \mathrm{C} / \mathrm{decade}$ (Hanssen-Bauer et al., 2019). During the normal period 19611990 , the average annual air temperature at Svalbard Airport was $-6.7^{\circ} \mathrm{C}$. It had increased to $-4.6{ }^{\circ} \mathrm{C}$ for the $1981-2010$ period. The strongest increase in temperature occurred during winter $\left(+3.5{ }^{\circ} \mathrm{C}\right)$ in contrast to the summer temperature $\left(+1{ }^{\circ} \mathrm{C}\right)$. This pronounced increase in temperature during the winter is a pattern observed at all weather stations in Svalbard. The increase in air temperature is expected to continue throughout the 21 st century, where different models imply an increase in the range of $+2.8^{\circ} \mathrm{C}$ to $+7.8^{\circ} \mathrm{C}$ (Førland et al., 2011). The air temperature increase was considerable lower in Northern Norway, with values of $+0.1^{\circ} \mathrm{C} /$ decade since 1901 , but $+0.5^{\circ} \mathrm{C} /$ decade between 1971-2000 and 1985-2014 (Hanssen-Bauer et al., 2015). According to the CryoGRID 1.0 model, approximately $27 \%$ of the land surface area of Northern Norway was underlain by permafrost in the period 1961-1990 (Farbrot et al., 2013). This area was reduced to $19 \%$ for the period 1981-2010, due to a temperature increase over the last decades. The degradation of permafrost and increase of temperature are expected to continue in the next decades (Farbrot et al., 2013).

The landform resemblance between Svalbard and Hopsfjorden both in assemblage and velocities is quite striking. However, the current framework conditions are not comparable. In Svalbard there is deep, cold and widespread permafrost, while in Hopsfjorden there is at most isolated patches of permafrost still present. The velocities of the Svalbard rock glaciers are probably because of low ground temperatures, and hence low ice plasticity, and gentler slopes on the strandflat. On the other hand, the low velocities of the Hopsfjorden rock glaciers are probably because of little pore ice left in the system. Rock glacier velocities tend to speed up when warmed (Kääb et al., 2007), and in this area, it seems that this stage in the development is passed. However, temperatures in Hopsfjorden during the LIA are probably comparable to the Western Spitsbergen temperatures today. In this way, the Hopsfjorden area can serve as a climatic and geomorphologic future analogue to Svalbard. 
In the recent IPA action group on rock glaciers' categorization, the term 'transitional' has been introduced for partly dynamic rock glaciers, those that are not active anymore, but not fully relict either. Exactly which processes the measured slope dynamics represent are difficult to interpret, most likely there is a combination of different processes; seasonal creep, rockslides, rock fall, snow avalanches, etc. This highlights the value of combining different methods in order to interpret the observations. It also shows that the traditional terminology of "relict" and "intact" landforms is not always sufficient (Ipa, 2020).

\section{Conclusions}

From this study, the following main conclusions can be drawn:

- The existence of coastal rock glaciers in northernmost Finnmark are widespread, and entirely conditioned by the bedrock type, with the major occurrence in the quartzite belts in the area.

- These rock glaciers may have formed after the early deglaciation in Late-Pleistocene. Rock glacier activity has probably varied between an active and inactive stage at several time periods in accordance with the Holocene climate fluctuations.

- The rock glacier observations from Hopsfjorden can be interpreted as landforms in transition from an active to a relict state in response to climate changes. The landforms that were initially interpreted as either intact or relict from aerial photos, are in fact not significantly different in terms of movement rates, exposition or climate. Our combined observations suggest that the location and visual appearance of the rock glaciers in the Hopsfjorden area is mostly dependent on the local bedrock and topography. However, the observed below zero summer temperatures in parts of the Ivarsfjorden rock glacier suggests that minor ice bodies in the landforms are still present.

- Our study finds relatively complex systems of rock glaciers, talus, landslides, and scree in close vicinity with variable creep rates depending on lithology and ground thermal state. These different landforms have similar morphology. This illustrates 1) the need of combining several methods when characterizing mountain permafrost landforms, and 2) the drawback of the traditional terminology to describe rock glacier activity state. It may be more accurate to address these systems as complex creeping systems that exist in various states of transition between a fully active rock glacier to a fully stabilized relict landform. 
https://doi.org/10.5194/esurf-2022-6

Preprint. Discussion started: 3 February 2022

(c) Author(s) 2022. CC BY 4.0 License.

\section{References}

Andersen, B. G.: Late Weichselian ice sheets in Eurasia, Greenland, and Norway, in: The Last Great Ice Sheets, edited by: Denton, G. H., and Hughes, T. J., John Wiley \& Sons, New York, USA, 20-27, 1981.

450 Ballantyne, C. K.: Paraglacial geomorphology, Quat. Sci. Rev., 21, 1935-2017, 2002.

Barsch, D.: Permafrost creep and rockglaciers, Permafrost and Periglacial Processes, 3, 175-188, 10.1002/ppp.3430030303, 1992.

Berthling, I.: Beyond confusion: Rock glaciers as cryo-conditioned landforms, Geomorphology, 131, 98-106,

10.1016/j.geomorph.2011.05.002, 2011.

Berthling, I., Etzelmüller, B., Eiken, T., and Sollid, J. L.: Rock glaciers on Prins Karls Forland, Svalbard. I: internal structure, flow

455 velocity and morphology, Permafrost and Periglacial Processes, 9, 135-145, doi:10.1002/(SICI)1099-1530(199804/06)9:2<135::AIDPPP284>3.0.CO;2-R, 1998.

Bertone, A., Rouyet, L., Strozzi, T., Kääb, A., Delaloye, R., and Bartsch, A.: Rock Glacier Kinematics as New Associated Parameter of ECV Permafrost, ESA Climate, 2020.

460 the last 60 years, The Cryosphere, 11, 1-16, 10.5194/tc-11-1-2017, 2017.

Boulton, G. S., Dongelmans, P., Punkari, M., and Broadgate, M.: Palaeoglaciology of an ice sheet through a glacial cycle: the European ice sheet through the Weichselian, Quat. Sci. Rev., 20, 591-625, https://doi.org/10.1016/S0277-3791(00)00160-8, 2001.

Dehls, J. F., Larsen, Y., Marinkovic, P., Lauknes, T. R., Stødle, D., and Moldestad, D. A.: INSAR.No: A National Insar Deformation Mapping/Monitoring Service In Norway -- From Concept To Operations, IGARSS 2019 - 2019 IEEE International Geoscience and

465 Remote Sensing Symposium, 28 July-2 Aug. 2019, 5461-5464, 10.1109/IGARSS.2019.8898614,

Delaloye, R. and Lambiel, C.: Evidence of winter ascending air circulation throughout talus slopes and rock glaciers situated in the lower belt of alpine discontinuous permafrost (Swiss Alps), Norsk Geografisk Tidsskrift - Norwegian Journal of Geography, 59, 194-203, 10.1080/00291950510020673, 2005.

Dowdeswell, J. A. and Siegert, M. J.: Ice-sheet numerical modeling and marine geophysical measurements of glacier-derived

470 sedimentation on the Eurasian Arctic continental margins, GSA Bulletin, 111, 1080-1097, 10.1130/0016-

7606(1999)111<1080:Isnmam>2.3.Co;2, 1999.

Egholm, D. L., Knudsen, M. F., and Sandiford, M.: Lifespan of mountain ranges scaled by feedbacks between landsliding and erosion by rivers, Nature, 498, 475, 10.1038/nature12218, 2013.

Etzelmüller, B., Patton, H., Schomacker, A., Czekirda, J., Girod, L., Hubbard, A., Lilleøren, K. S., and Westermann, S.: Icelandic

475 permafrost dynamics since the Last Glacial Maximum - model results and geomorphological implications, Quat. Sci. Rev., 233, 106236, https://doi.org/10.1016/j.quascirev.2020.106236, 2020.

Farbrot, H., Isaksen, K., and Etzelmüller, B.: Present and past distribution of mountain permafrost in Gaissane Mountains, Northern Norway, Ninth International Conference on Permafrost, University of Alaska, Fairbanks, 427-432,

Farbrot, H., Isaksen, K., Etzelmüller, B., and Gisnås, K.: Ground Thermal Regime and Permafrost Distribution under a Changing Climate

480 in Northern Norway, Permafrost and Periglacial Processes, n/a-n/a, 10.1002/ppp.1763, 2013.

Farbrot, H., Isaksen, K., Eiken, T., Kääb, A., and Sollid, J. L.: Composition and internal structures of a rock glacier on the strandflat of western Spitsbergen, Svalbard, Norsk Geografisk Tidsskrift, 59, 139-148, 2005.

Farbrot, H., Etzelmüller, B., Gudmundsson, A., Humlum, O., Kellerer-Pirklbauer, A., Eiken, T., and Wangensteen, B.: Rock glaciers and permafrost in Trollaskagi, northern Iceland, Zeitschrift Fur Geomorphologie, 51, 1-16, 10.1127/0372-8854/007/0051s2-0001, 2007.

485 Fjellanger, J., Sørbel, L., Linge, H., Brook, E. J., Raisbeck, G. M., and Yiou, F.: Glacial survival of blockfields on the Varanger Peninsula, northern Norway, Geomorphology, 82, 255-272, 10.1016/j.geomorph.2006.05.007, 2006.

Førland, E. J., Benestad, R., Hanssen-Bauer, I., Haugen, J. E., and Skaugen, T. E.: Temperature and Precipitation Development at Svalbard 1900\&\#8211;2100, Advances in Meteorology, 2011, 14, 10.1155/2011/893790, 2011.

Gisnås, K., Westermann, S., Schuler, T. V., Melvold, K., and Etzelmüller, B.: Small-scale variation of snow in a regional permafrost

490 model, The Cryosphere, 10, 1201-1215, 10.5194/tc-10-1201-2016, 2016.

Gisnås, K., Etzelmüller, B., Lussana, C., Hjort, J., Sannel, A. B. K., Isaksen, K., Westermann, S., Kuhry, P., Christiansen, H. H., Frampton, A., and Åkerman, J.: Permafrost Map for Norway, Sweden and Finland, Permafrost and Periglacial Processes, 28, 359-378, doi:10.1002/ppp.1922, 2017.

Gubler, S., Fiddes, J., Keller, M., and Gruber, S.: Scale-dependent measurement and analysis of ground surface temperature variability in

495 alpine terrain, The Cryosphere, 5, 431-443, 10.5194/tc-5-431-2011, 2011.

Haeberli, W.: Creep of mountain permafrost: internal structure and flow of Alpine rock glaciers., ETH, Zürich, $142,1985$.

Haeberli, W., Hallet, B., Arenson, L., Elconin, R., Humlum, O., Kaab, A., Kaufmann, V., Ladanyi, B., Matsuoka, N., Springman, S., and Vonder Muhll, D.: Permafrost creep and rock glacier dynamics, Permafrost and Periglacial Processes, 17, 189-214, 10.1002/ppp.561, 2006.

500 Hales, T. C. and Roering, J. J.: Climatic controls on frost cracking and implications for the evolution of bedrock landscapes, Journal of Geophysical Research: Earth Surface, 112, 10.1029/2006jf000616, 2007. 
https://doi.org/10.5194/esurf-2022-6

Preprint. Discussion started: 3 February 2022

(c) Author(s) 2022. CC BY 4.0 License.

Hales, T. C. and Roering, J. J.: A frost "buzzsaw" mechanism for erosion of the eastern Southern Alps, New Zealand, Geomorphology, 107, 241-253, https://doi.org/10.1016/i.geomorph.2008.12.012, 2009.

Hanssen-Bauer, I., Førland, E. J., Haddeland, I., Hisdal, H., Mayer, S., Nesje, A., Nilsen, J. E. Ø., Sandven, S., Sandø, A. B., Sorteberg,

505 A., Ådlandsvik, B., Andreassen, L. M., Beldring, S., Bjune, A., Breili, K., Breivik, Ø., Dahl, C. A., Dyrrdal, A. V., Isaksen, K., Haakenstad, N., Haugen, J. E., Hygen, H. O., Langehaug, H. R., Lauritzen, S.-E., Melvold, K., Ravndal, O., Risebrobakken, B., Roald, L., Sande, M. J. R., Simpson, M. J. R., Skagseth, Ø., Skaugen, T., Skogen, M., Støren, E. N., Tveito, O. E., and Wong, W. K.: Klima i Norge 2100 - Kunnskapsgrunnlag for klimatilpasning, Miljødirektoratet, 204, 2015.

Hanssen-Bauer, I., Førland, E. J., Hisdal, H., Mayer, S., Sandø, A. B., Sorteberg, A., Adakudlu, M., Andresen, J., Bakke, J., Beldring, S.,

510 Benestad, R., Bilt, W., Bogen, J., Borstad, C., Breili, K., Breivik, Ø., Børsheim, K. Y., Christiansen, H. H., Dobler, A., Engeset, R., Frauenfelder, R., Gerland, S., Gjelten, H. M., Gundersen, J., Isaksen, K., Jaedicke, C., Kierulf, H. P., Kohler, J., Li, H., Lutz, J., Melvold, K., Mezghani, A., Nilsen, F., Nilsen, I. B., Nilsen, J. E. Ø., Pavlova, O., Ravndal, O., Risebrobakken, B., Saloranta, T., Sandven, S., Schuler, T. V., Simpson, M. J. R., Skogen, M., Smedsrud, L. H., Sund, M., Vikhamar-Schuler, D., Westermann, S., and Wong, W. K.: Climate in Svalbard 2100 - a knowledge base for climate adaptation, The Norwegian Environment Agency, $207,2019$.

515 Harris, C. and Vonder Muhll, D.: Permafrost and climate in Europe. Climate change, mountain permafrost degradation and geotechnical hazard, in: Global Change and Protected Areas, edited by: Visconti, G., Beniston, M., Iannorelli, E. D., and Barba, D., Advances in Global Change Research, 71-82, 2001.

Harris, S. A. and Corte, A. E.: Interactions and relations between mountain permafrost, glaciers, snow and water, Permafrost and Periglacial Processes, 3, 103-110, 10.1002/ppp.3430030207, 1992.

520 Hauck, C. and Kneisel, C. (Eds.): Applied geophysics in periglacial environments, Campbridge University Press, 2008.

Hauck, C., Böttcher, M., and Maurer, H.: A new model for estimating subsurface ice content based on combined electrical and seismic data sets, The Cryosphere, 5, 453-468, 10.5194/tc-5-453-2011, 2011.

Heid, T. and Kääb, A.: Evaluation of existing image matching methods for deriving glacier surface displacements globally from optical satellite imagery, Remote Sensing of Environment, 118, 339-355, https://doi.org/10.1016/j.rse.2011.11.024, 2012.

525 Hilbich, C.: Time-lapse refraction seismic tomography for the detection of ground ice degradation, The Cryosphere, 4, 10.5194/tc-4-243$2010,2010$.

Humlum, O., Christiansen, H. H., and Juliussen, H.: Avalanche-derived rock glaciers in Svalbard, Permafrost and Periglacial Processes, 18, 75-88, https://doi.org/10.1002/ppp.580, 2007.

Ikeda, A. and Matsuoka, N.: Pebbly versus bouldery rock glaciers: Morphology, structure and processes, Geomorphology, 73, 279-296,

530 https://doi.org/10.1016/j.geomorph.2005.07.015, 2006.

IPA: Kinematics as an optional attribute in standardized rock glacier inventories., Version 2.1, IPA Action Group Rock glacier inventories and kinematics, 2020.

Isaksen, K., Ødegård, R. S., Eiken, T., and Sollid, J. L.: Composition, flow and development of two tongue-shaped rock glaciers in the permafrost of Svalbard, Permafrost and Periglacial Processes, 11, 241-257, 2000.

535 Kenner, R., Phillips, M., Hauck, C., Hilbich, C., Mulsow, C., Bühler, Y., Stoffel, A., and Buchroithner, M.: New insights on permafrost genesis and conservation in talus slopes based on observations at Flüelapass, Eastern Switzerland, Geomorphology, 290, 101-113, https://doi.org/10.1016/j.geomorph.2017.04.011, 2017.

King, L.: Zonation and Ecology of High Mountain Permafrost in Scandinavia, Geografiska Annaler Series A - Physical Geography, 68, $131-139,1986$.

540 Kjellman, S. E., Axelsson, P. E., Etzelmüller, B., Westermann, S., and Sannel, A. B. K.: Holocene development of subarctic permafrost peatlands in Finnmark, northern Norway, The Holocene, 28, 1855-1869, 10.1177/0959683618798126, 2018.

Kääb, A. and Vollmer, M.: Surface Geometry, Thickness Changes and Flow Fields on Creeping Mountain Permafrost: Automatic Extraction by Digital Image Analysis, Permafrost and Periglacial Processes, 11, 315-326, doi:10.1002/1099-1530(200012)11:4<315::AIDPPP365>3.0.CO;2-J, 2000.

545 Kääb, A., Frauenfelder, R., and Roer, I.: On the response of rockglacier creep to surface temperature increase, Global and Planetary Change, 56, 172-187, 10.1016/j.gloplacha.2006.07.005, 2007.

Lambiel, C. and Pieracci, K.: Permafrost distribution in talus slopes located within the alpine periglacial belt, Swiss Alps, Permafrost and Periglacial Processes, 19, 293-304, https://doi.org/10.1002/ppp.624, 2008.

Liestøl, O.: Talus terraces in Arctic regions, Norsk polarinstitutts Aarbok, 102-105, 1961.

550 Lilleøren, K. S. and Etzelmüller, B.: A regional inventory of rock glaciers and ice-cored moraines in Norway, Geografiska Annaler Series A - Physical Geography, 93, 175-191, 10.1111/j.1468-0459.2011.00430.x, 2011.

Lilleøren, K. S., Etzelmüller, B., Gärtner-Roer, I., Kääb, A., Westermann, S., and Guðmundsson, Á.: The Distribution, Thermal Characteristics and Dynamics of Permafrost in Tröllaskagi, Northern Iceland, as Inferred from the Distribution of Rock Glaciers and IceCored Moraines, Permafrost and Periglacial Processes, 24, 322-335, 10.1002/ppp.1792, 2013.

555 Tutorial: 2-D and 3-D electrical imaging surveys: www.geotomosoft.com/downloads.php, last Loke, M. H. and Barker, R. D.: Practical techniques for 3D resistivity surveys and data inversion, Geophysical Prospecting, 44, 499-523, 10.1111/j.1365-2478.1996.tb00162.x, 1996a. 
https://doi.org/10.5194/esurf-2022-6

Preprint. Discussion started: 3 February 2022

(c) Author(s) 2022. CC BY 4.0 License.

Loke, M. H. and Barker, R. D.: Rapid least-squares inversion of apparent resistivity pseudosections by a quasi-Newton method, Geophysical Prospecting, 44, 131-152, 10.1111/j.1365-2478.1996.tb00142.x, 1996b.

560 Lussana, C., Saloranta, T., Skaugen, T., Magnusson, J., Tveito, O. E., and Andersen, J.: seNorge2 daily precipitation, an observational gridded dataset over Norway from 1957 to the present day, Earth Syst. Sci. Data, 10, 235-249, 10.5194/essd-10-235-2018, 2018.

Malmström, B. and Palmér, O.: Glacial and periglacial geomorphology on the Varanger peninsula, Northern Norway. Geomophological mapping with analysis of glacial forms and block fields., The Royal University of Lund, Sweden 1984.

Matsuoka, N. and Ikeda, A.: Geological control on the distribution and characteristics talus-derived rock glaciers., Annual Report of the

565 Institute of Geosciences, University of Tsukuba, Japan, 27, 11-16, 2001.

McColl, S. T.: Paraglacial rock-slope stability, Geomorphology, 153-154, 1-16, https://doi.org/10.1016/j.geomorph.2012.02.015, 2012.

Meier, K.-D.: Studien zur Periglaziärmorphologie der Varanger-Halbinsel, Nordnorwegen, Arbeitskreises für geographische

Nordeuropaforschung in der Deutschen Gesellschaft für Geographie, Bremen, Germany, 405, 1987.

Nordli, Ø., Przybylak, R., Ogilvie, A. E. J., and Isaksen, K.: Long-term temperature trends and variability on Spitsbergen: the extended

570 Svalbard Airport temperature series, 1898-2012, Polar Research, 33, 21349, 10.3402/polar.v33.21349, 2014.

Obu, J., Westermann, S., Kääb, A., and Bartsch, A.: Ground Temperature Map, 2000-2016, Northern Hemisphere Permafrost, PANGAEA [dataset], 10.1594/PANGAEA.888600, 2018.

Ottesen, D., Dowdeswell, J. A., and Rise, L.: Submarine landforms and the reconstruction of fast-flowing ice streams within a large Quaternary ice sheet: The 2500-km-long Norwegian-Svalbard margin $\left(57^{\circ}-80^{\circ} \mathrm{N}\right)$, GSA Bulletin, 117, 1033-1050, 10.1130/b25577.1,

5752005.

Romundset, A., Bondevik, S., and Bennike, O.: Postglacial uplift and relative sea level changes in Finnmark, northern Norway, Quat. Sci. Rev., 30, 2398-2421, https://doi.org/10.1016/j.quascirev.2011.06.007, 2011.

Rouyet, L., Lilleøren, K. S., Böhme, M., Vick, L. M., Delaloye, R., Etzelmüller, B., Lauknes, T. R., Larsen, Y., and Blikra, L. H.: Regional Morpho-Kinematic Inventory of Slope Movements in Northern Norway, Frontiers in Earth Science, 9 ,

$580 \quad 10.3389 /$ feart.2021.681088, 2021.

Saloranta, T.: Simulating snow maps for Norway: Description and statistical evaluation of the seNorge snow model, The Cryosphere, Volume 6, Issue 6, 2012, pp.1323-1337, 6, 1323-1337, 10.5194/tc-6-1323-2012, 2012a.

Saloranta, T. M.: Simulating snow maps for Norway: description and statistical evaluation of the seNorge snow model, The Cryosphere, 6 , 1323-1337, 10.5194/tc-6-1323-2012, 2012b.

585 Sandwell, D. T. and Price, E. J.: Phase gradient approach to stacking interferograms, Journal of Geophysical Research: Solid Earth, 103, 30183-30204, https://doi.org/10.1029/1998JB900008, 1998.

Schilling, J., Reimann, C., and Roberts, D.: REE potential of the Nordkinn Peninsula, North Norway: A comparison of soil and bedrock composition, Applied Geochemistry, 41, 95-106, https://doi.org/10.1016/j.apgeochem.2013.12.004, 2014.

Shackleton, C., Patton, H., Hubbard, A., Winsborrow, M., Kingslake, J., Esteves, M., Andreassen, K., and Greenwood, S. L.: Subglacial

590 water storage and drainage beneath the Fennoscandian and Barents Sea ice sheets, Quat. Sci. Rev., 201, 13-28, https://doi.org/10.1016/i.quascirev.2018.10.007, 2018.

Sollid, J. L. and Sørbel, L.: Rock glaciers in Svalbard and Norway, Permafrost and Periglacial Processes, 3, 215-220, 1992.

Sollid, J. L. and Sørbel, L.: Palsa Bogs as a climate indicator - Examples from Dovrefjell, Southern Norway, Ambio, 27, 287-291, 1998.

Sollid, J. L., Andersen, S. T., Hamre, N., Kjeldsen, O., Salvigsen, O., Sturød, S., Tveitå, T., and Wilhelmsen, A.: Deglaciation of

595 Finnmark, North Norway,. Norsk geografisk tidsskrift - Norwegian Journal of Geography, 27, 233-325, 1973.

Svensson, H.: Note on a type of patterned ground on the Varanger peninsula, Norway, Geografiska Annaler, 44, 413, 1962.

Svensson, H.: Permafrost. Some Morphoclimatic Aspects of Periglacial Features of Northern Scandinavia, Geografiska Annaler: Series A, Physical Geography, 68, 123-130, 10.1080/04353676.1986.11880165, 1986.

Svensson, H.: Frost-fissure patterns in the Nordic countries, Geografiska Annaler Series A - Physical Geography, 74, $207-218,1992$.

600 van Everdingen, R. O. e.: Multi-language glossary of permafrost and related ground-ice terms, International Permafrost Association, the University of Calgary, Calgary, 1998.

Vick, L. M., Böhme, M., Rouyet, L., Bergh, S. G., Corner, G. D., and Lauknes, T. R.: Structurally controlled rock slope deformation in northern Norway, Landslides, 17, 1745-1776, 10.1007/s10346-020-01421-7, 2020.

Vikhamar-Schuler, D., Hanssen-Bauer, I., and Førland, E. J.: Long-term climate trends of Finnmarksvidda, Northern Norway, Norwegian

605 Meterological Institute (MET), Oslo, Norway, 41, 2010.

Wicky, J. and Hauck, C.: Numerical modelling of convective heat transport by air flow in permafrost talus slopes, The Cryosphere, 11, 1311-1325, 10.5194/tc-11-1311-2017, 2017.

Winsborrow, M. C. M., Andreassen, K., Corner, G. D., and Laberg, J. S.: Deglaciation of a marine-based ice sheet: Late Weichselian palaeo-ice dynamics and retreat in the southern Barents Sea reconstructed from onshore and offshore glacial geomorphology, Quat. Sci.

610 Rev., 29, 424-442, https://doi.org/10.1016/j.quascirev.2009.10.001, 2010.

Yuki, S., Ishikawa, M., and Ono, Y.: Thermal regime of sporadic permafrost in a block slope on Mt. Nishi-Nupukaushinupuri, Hokkaido Island, Northern Japan, Geomorphology, 52, 121-130, 10.1016/S0169-555X(02)00252-0, 2003. 
https://doi.org/10.5194/esurf-2022-6

Preprint. Discussion started: 3 February 2022

(c) Author(s) 2022. CC BY 4.0 License.
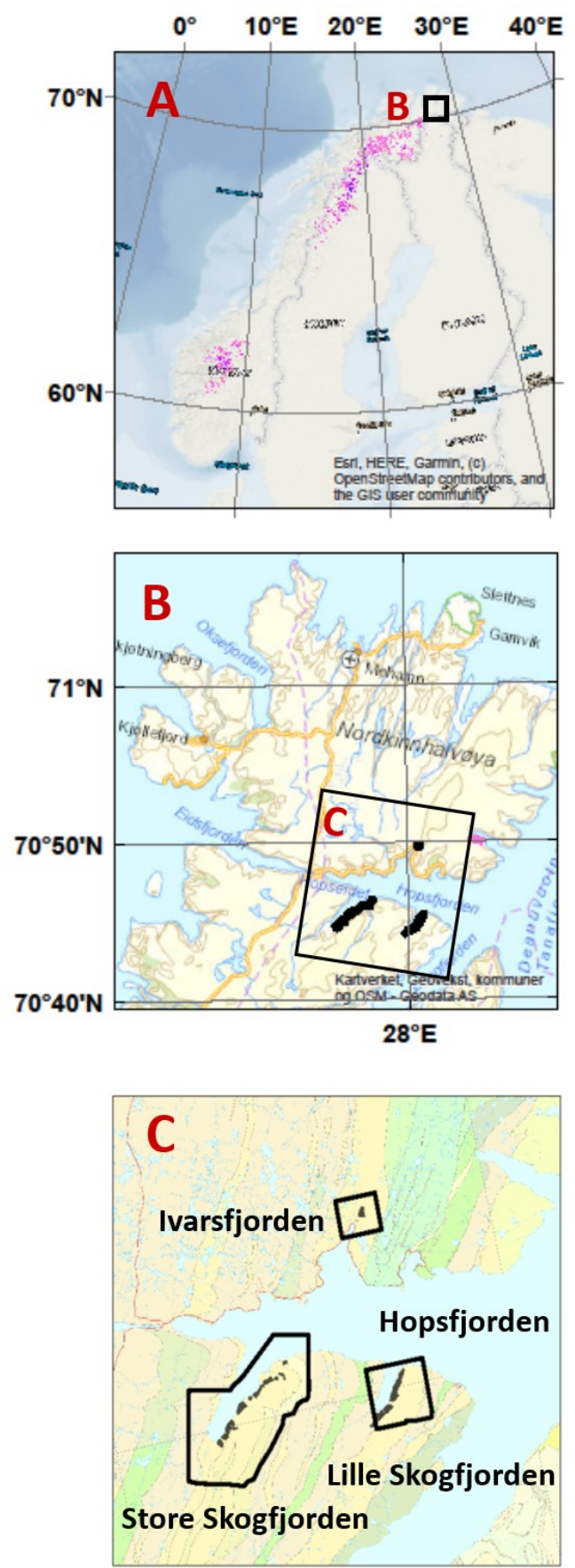

Earth Surface

Dynamics

Discussions (c) (i)

615
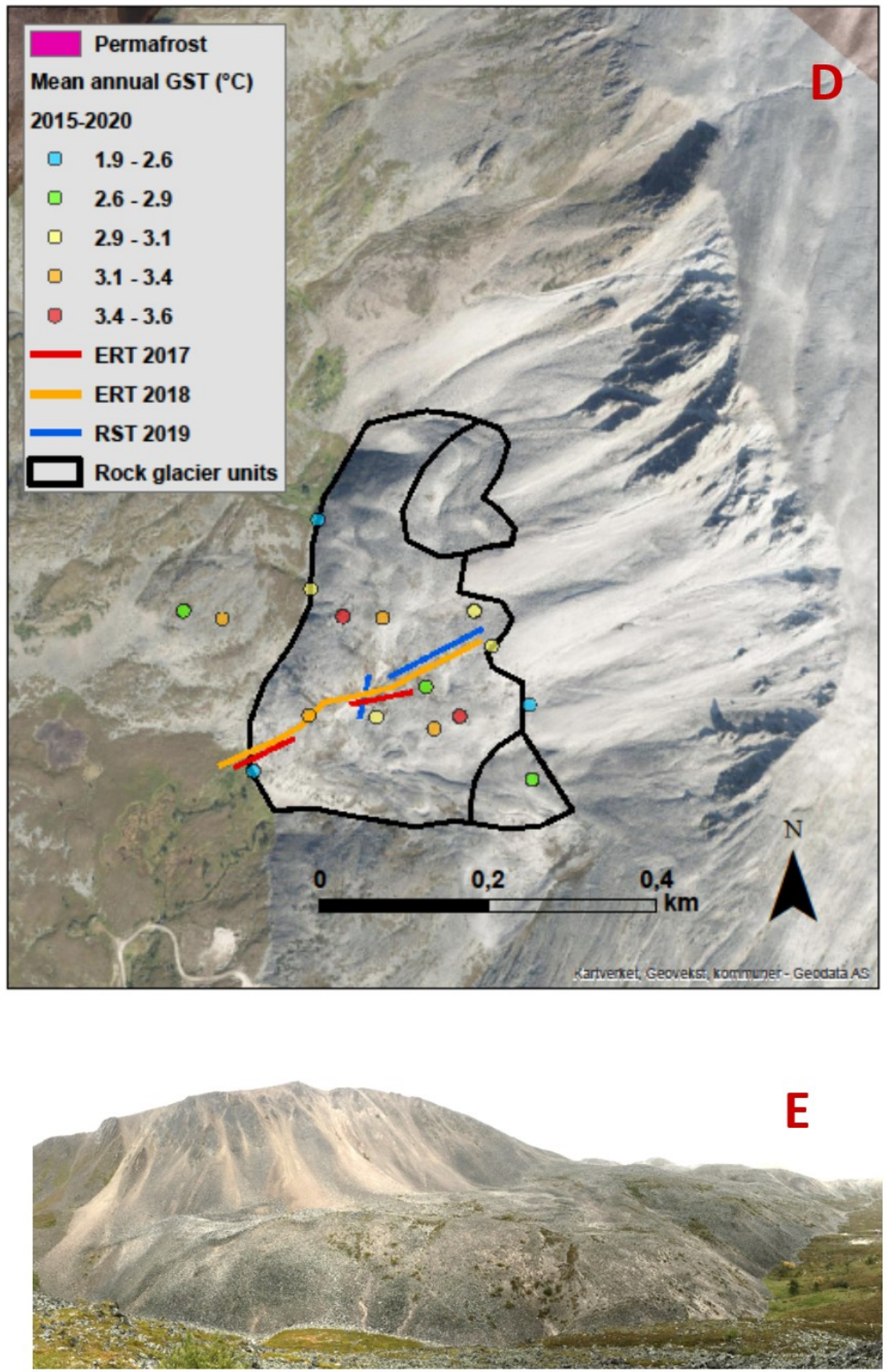

Rock glacier

Sandstone, phyllite

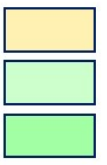

Sandstone with quartzite

Phyllite, siltstone, sandstone

Phyllite, siltstone 
https://doi.org/10.5194/esurf-2022-6

Preprint. Discussion started: 3 February 2022

(c) Author(s) 2022. CC BY 4.0 License.

Figure 1: A: Overview map of Norway, Sweden and Finland (C) ESRI and OpenStreetMap contributers), with our study area indicated by the black square B. Probable permafrost presence as modelled in Gisnås et al. (2017) is shown in pink. B: Closer view of Nordkinn peninsula, with the location of the inlet map C (C) Norwegian Mapping Authority). Rock glacier units are marked in black. C: Geological map of the Hopsfjorden area (CNorwegian Geological Survey). The black boxes are similar to the geomorphological maps in Fig. 2. D: Ivarsfjorden rock glacier, with mean annual ground surface temperatures (GST; 2015-2020). The lines on the rock glacier are profiles of Electrical Resistivity Tomography (ERT) from two years (2017; red, and 2018; orange) and Refraction Seismic Tomography (RST) from 2019 (blue). E: Picture of the Ivarsfjorden rock glacier, taken towards east. 


\section{Legend}

a Till

ก Hummocks

- Polygons

- Solifluction lobe

$\Delta$ Boulder-rich surface

* Patterned ground (frost-sorted landforms)

- Debris flow depost

u Beach ridge

E Fluvial deposit

sp Rock fall

$2,,-$ Relict drainage parth

$\mapsto \mapsto$ Gully

$\therefore$ Drainage path, active

$\rightarrow$, Drainage path, relict

, , Terrace edge

....... Beach ridge

Avalanche deposit

-Debris flow track

Distinct avalanche path

" "-Scarp

Rock glacier front edge

TTII

Marine deposit, unspecified

Fluvial deposit

Weathered material

Mass-movement material

Rock glacier, fresh surface

Rock glacier, relict surface

Rock fall deposit

Snow avalanche deposit

VII Debris flow deposit

Solifluction material

Stone-rich solifluction material

Exposed bedrock

Exposed bedrock, thin sediment cover
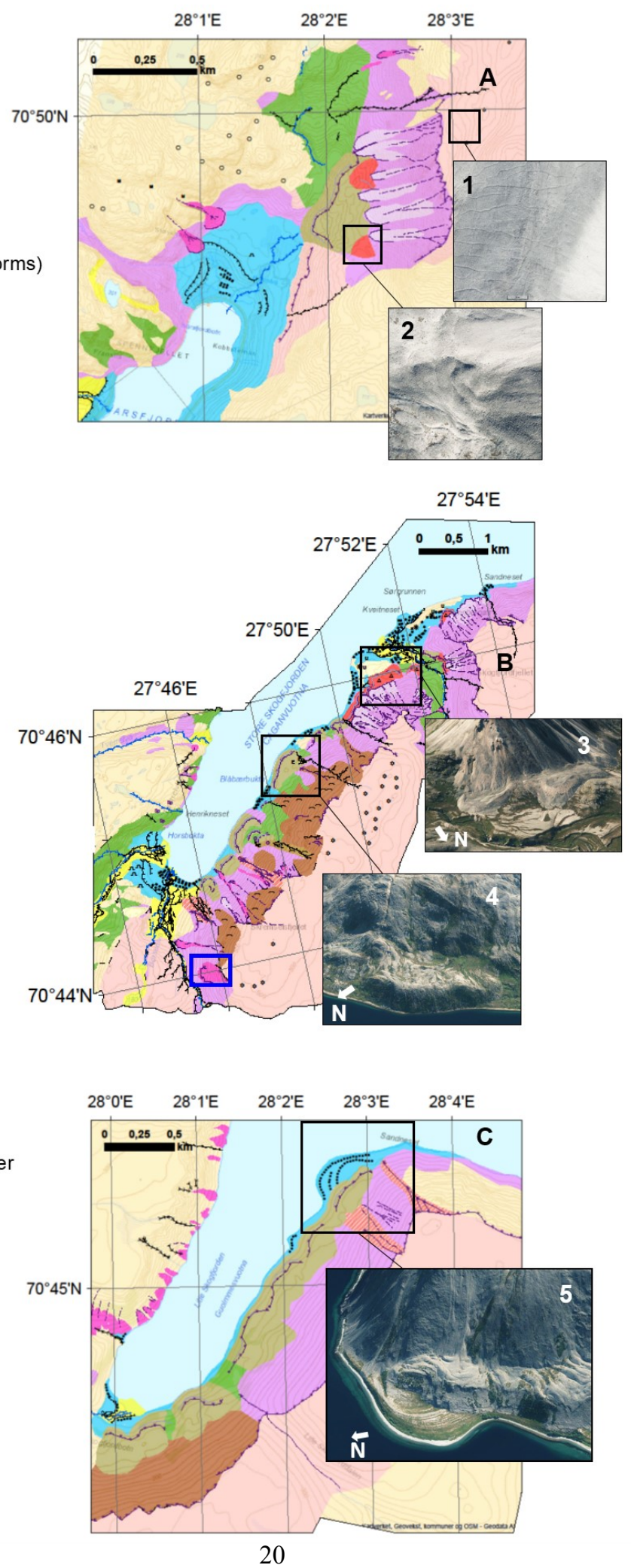
Figure 2: Geomorphological maps of (A) Ivarsfjorden, (B) Store Skogfjorden, and (C) Lille Skogfjorden. The inset images show from the top: 1. polygonal network pattern on the Sandfjellet plateau, 2. the currently most active part of Ivarsfjorden rock glacier, 3. intact rock glacier north in Store Skogfjorden, with raised shore lines, 4. relict rock glacier in mid-Store Skogfjorden, and 5. intact rock glacier crossing raised shorelines north in Lille Skogfjorden. The blue square southwest in fig. 2b indicates the location of the rockslide shown in Fig. 3. All topographical background maps are the owned by the Norwegian Mapping Authority.
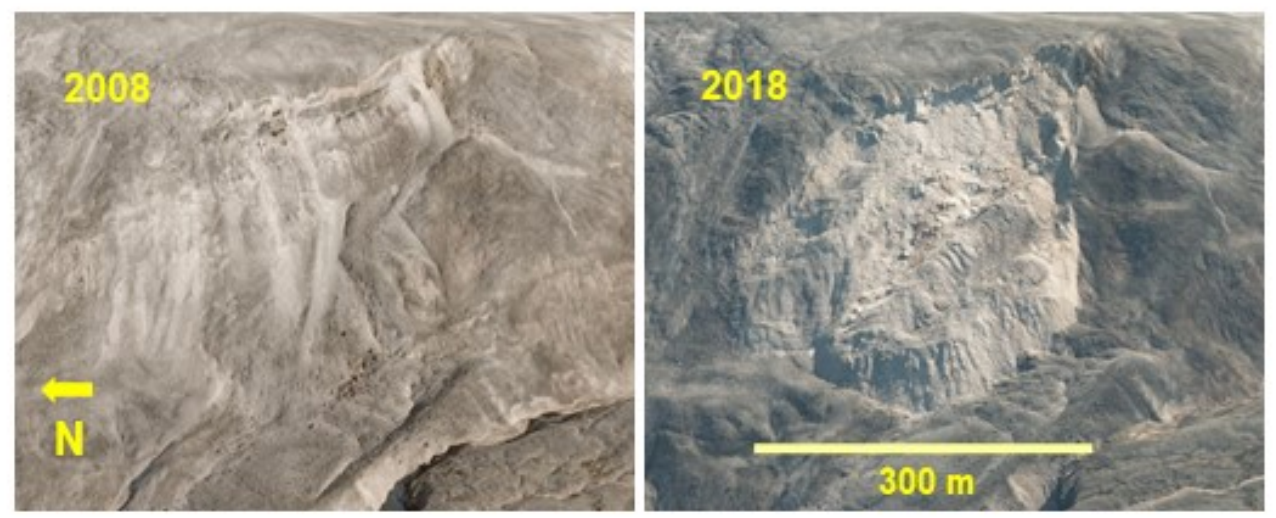

Figure 3: Rockslide south of Store Skogfjorden as it appears in aerial photos prior to the event (2008) and after it occurred (2018). Photos are retrieved from www.norgeibilder.no (3D version), owned by the Norwegian Mapping Authority. The 2008 photo, part of the Kongsfjorden campaign, was taken on the 19th August 2008, while the 2018 photo, part of the Finnmark campaign, was taken on the 18th July 2018. The rockslide is about $300 \mathrm{~m}$ wide, and the upper scar is $15-20 \mathrm{~m}$ tall. The location is shown in Fig. $2 \mathrm{~B}$. 
https://doi.org/10.5194/esurf-2022-6

Preprint. Discussion started: 3 February 2022

(c) Author(s) 2022. CC BY 4.0 License.
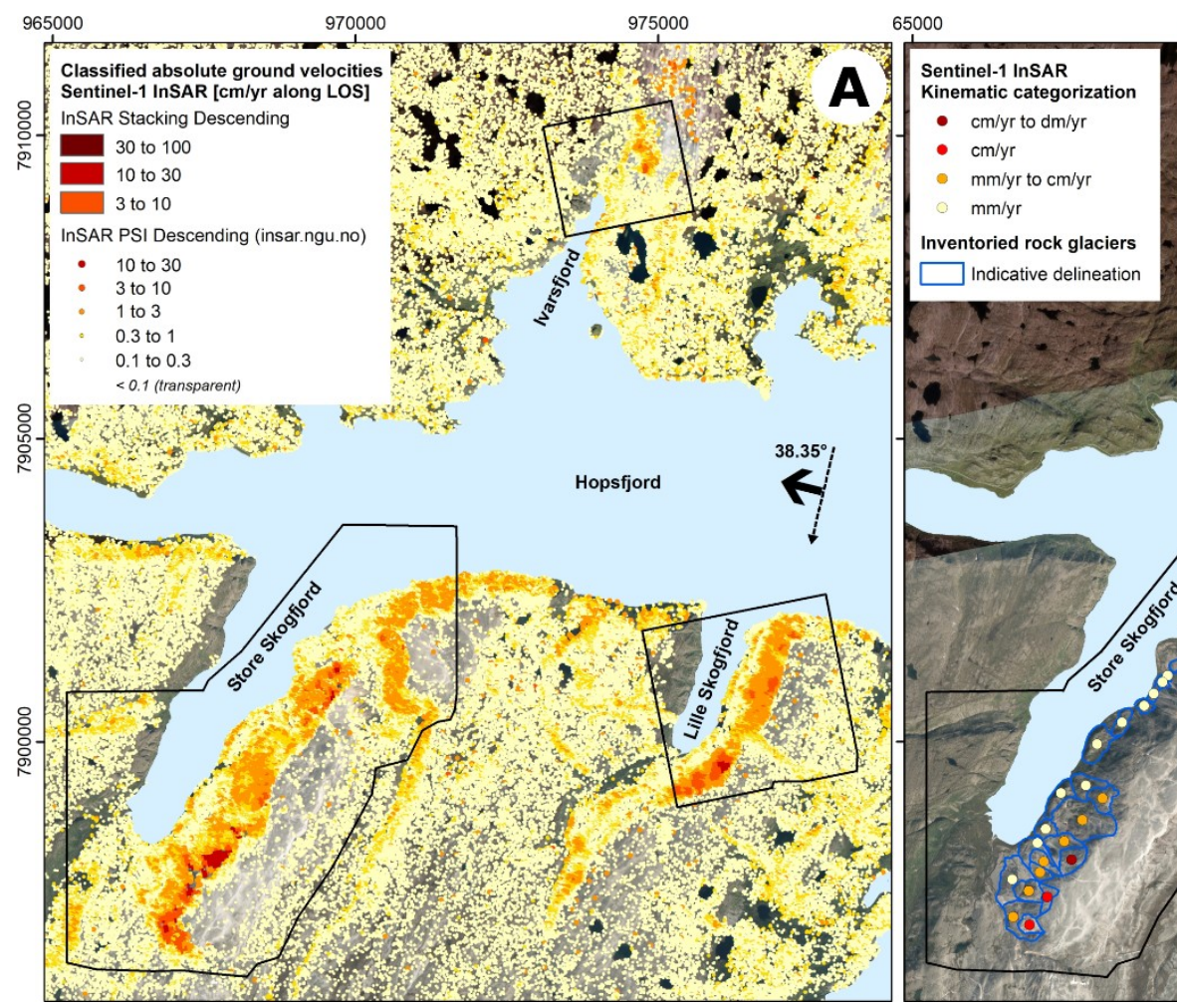

Inventoried rock glaciers

$\square$ Indicative delineation

970000

975000
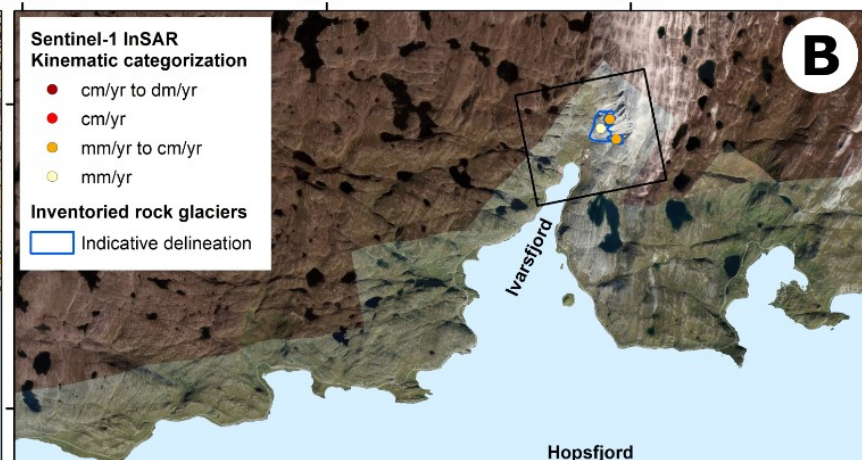

Hopsfjord

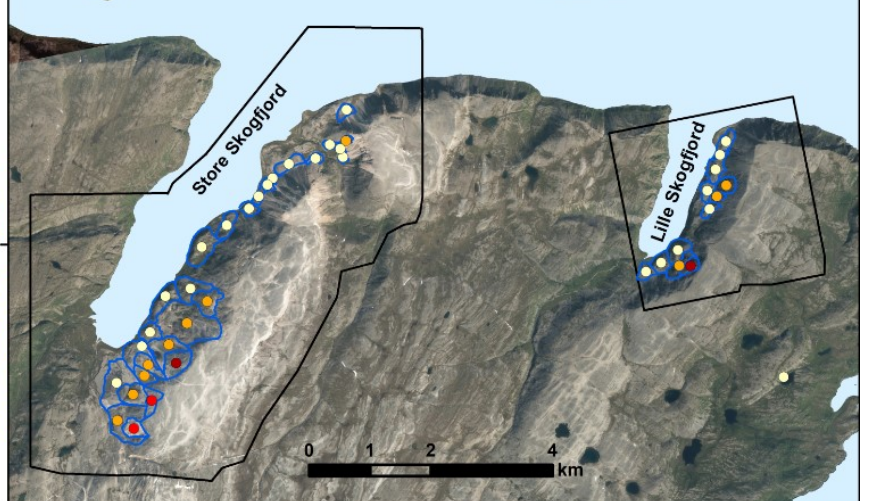

Figure 4: A) Composite InSAR map based on classified absolute ground velocities from snow-free Sentinel-1 satellite images (JuneOctober) between 2015 and 2020 (descending geometry). The map combines results processed with a stacking method (Rouyet et al., 2021) and a Persistent Scatterers Interferometry (PSI) method (NGU, 2020; Dehls et al. 2019). The black polygons show the extents of the geomorphological maps from fig. 2. The black arrow shows the direction of the flying satellite (dashed line) and the corresponding radar line-of-sight (LOS) towards WNW. The label indicates the angle between the vertical and the LOS. B) Indicative delineation of rock glacier units and associated kinematic attribute (order of magnitude of the creep rate) based on Sentinel-1 InSAR velocity from A. 
https://doi.org/10.5194/esurf-2022-6

Preprint. Discussion started: 3 February 2022

(c) Author(s) 2022. CC BY 4.0 License.
Earth Surface

Dynamics

Discussions

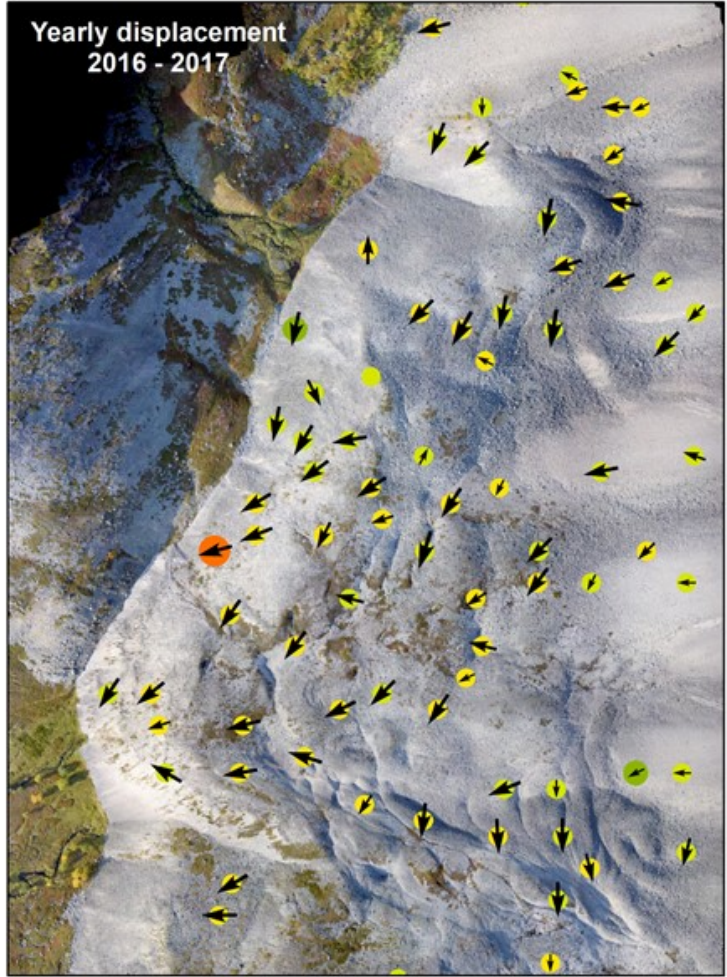

Horizontal displacement

( $\mathrm{m} /$ year)

$\uparrow<0.01$

$\uparrow \quad 0.01-0.015$

$\uparrow \quad 0.015-0.02$

$\uparrow \quad 0.02-0.1$

$\uparrow>0.1$

Vertical displacement

( $\mathrm{m} /$ year)

$<<-0.1$

$-0.1--0.05$

$-0.05-0$

$0-0.05$

$0.05-0.1$

$>0.1$ 
https://doi.org/10.5194/esurf-2022-6

Preprint. Discussion started: 3 February 2022

(c) Author(s) 2022. CC BY 4.0 License.

Figure 5: Yearly displacement of Ivarsfjorden rock glacier between in the time periods 1975-2017 (top left), $2016-2017$ (top right), and 2017-2020 (bottom left). The arrows show length and direction of horizontal movement, while the circles show vertical changes. Negative values means lowering of the ground, positive values means higher ground in the time periods. All numbers are given in meters per year.

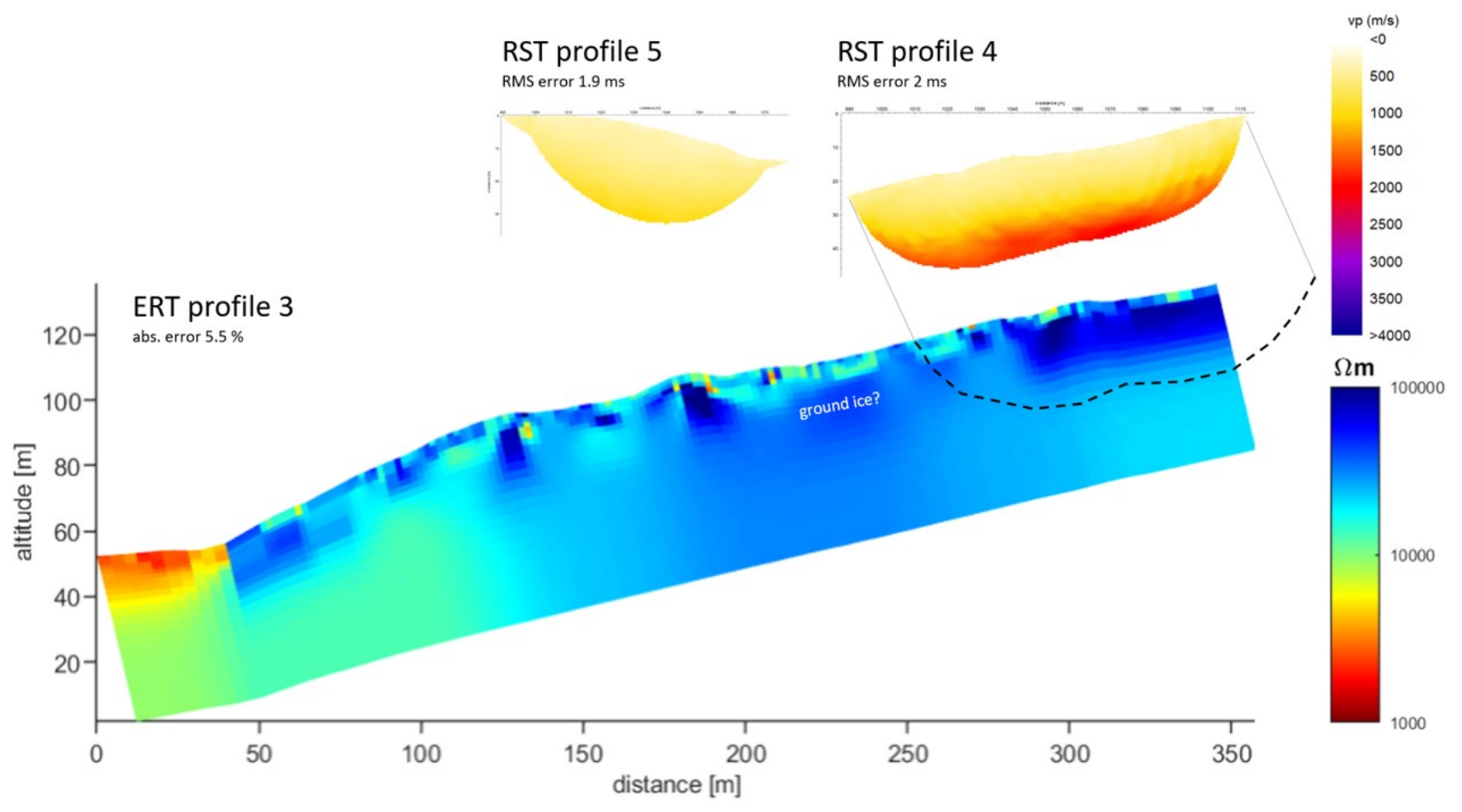

Figure 6: The long Electrical Resistivity Tomography (ERT) profile retrieved in 2018, and two Refraction Seismic Tomography (RST) profiles retrieved in 2019 (all locations in fig. 1). The X marks where the RST profile normal to slope crosses the ERT profile. Blue colours in the ERT profile mean high resistivity (above $10000 \Omega \mathrm{m}$ ), while yellow and red colours in the RST profiles means low wave propagation (below $2000 \mathrm{~m} \mathrm{~s}^{-1}$ ). 
https://doi.org/10.5194/esurf-2022-6

Preprint. Discussion started: 3 February 2022

(c) Author(s) 2022. CC BY 4.0 License.

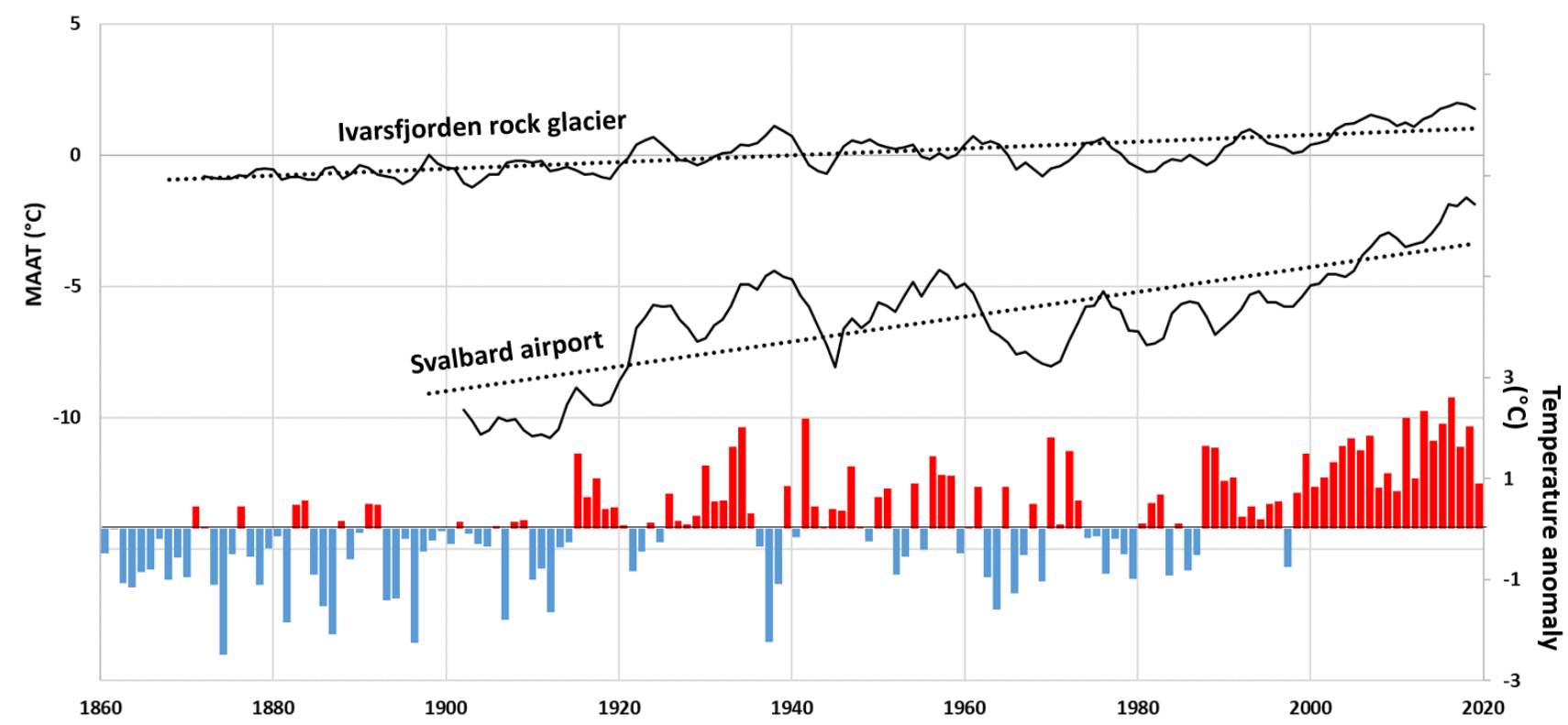

Figure 7: Mean annual air temperature of Ivarsfjorden rock glacier (combined by SeNorge data from 1957 to present, and by extrapolating the data series based on Vardo radio temperature observations starting in 1868), and the composite temperature records from Svalbard airport (Nordli et al., 2014) updated to 2020. Both series are shown as the running average of 5 years (full

line) and the linear trendlines (dotted lines). The lower graph is a temperature anomaly plot of yearly temperatures at Ivarsfjorden rock glacier compared to the 1961-90 normal period. 

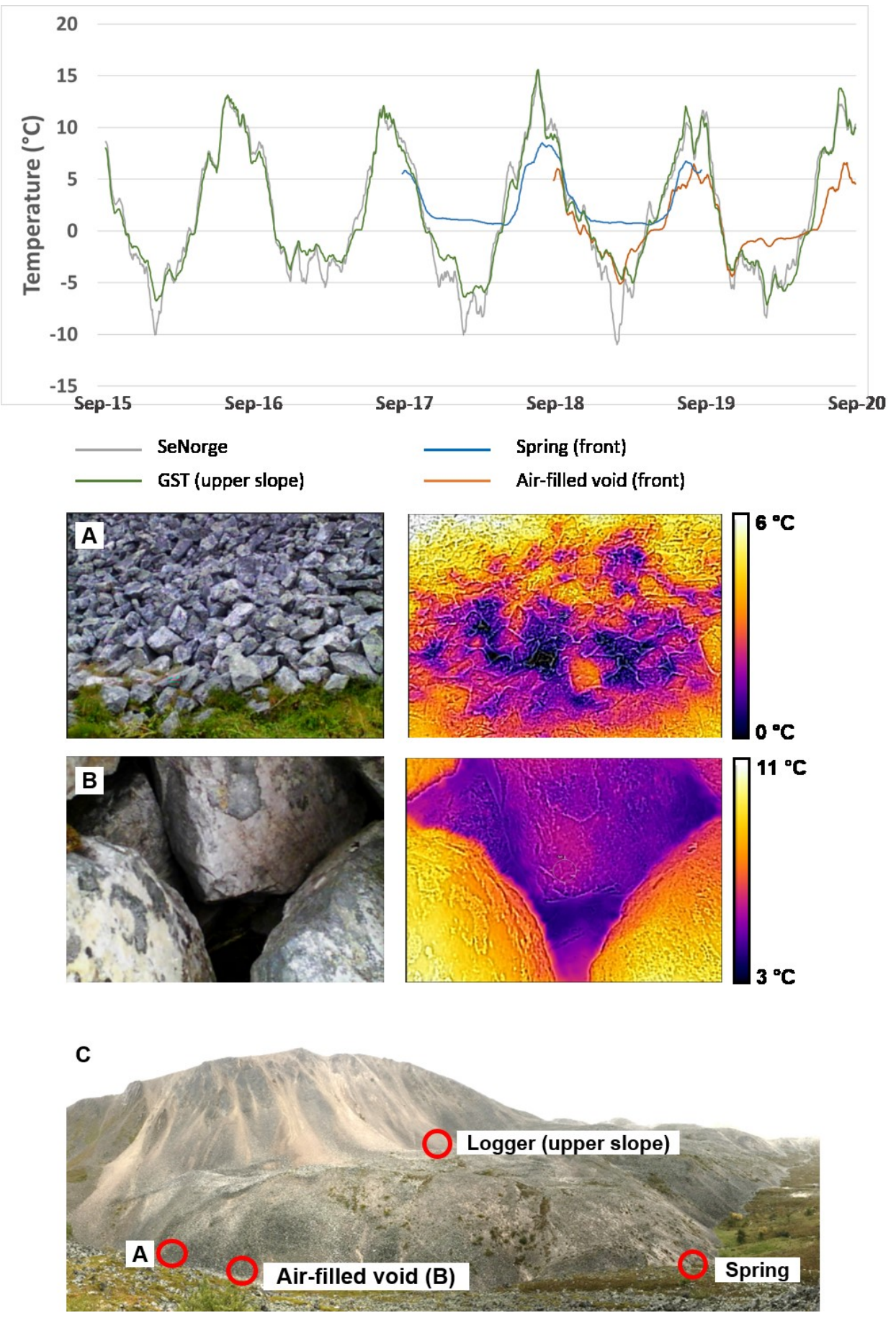

Figure 8: A: Air and ground surface temperature over the 5 years of monitoring. The graph shows daily temperatures smoothed over 20 days; grey: SeNorge air temperature; green: ground surface temperature (GST) close to the top of the rock glacier; blue: spring escaping from the rock glacier front; orange: open blocks in the rock glacier front (positions indicated in image D. Images B and $C$ show optical (left) and thermal (right) image of the rock glacier front. Positions can be found in image $D$. Image $B$ is also the 

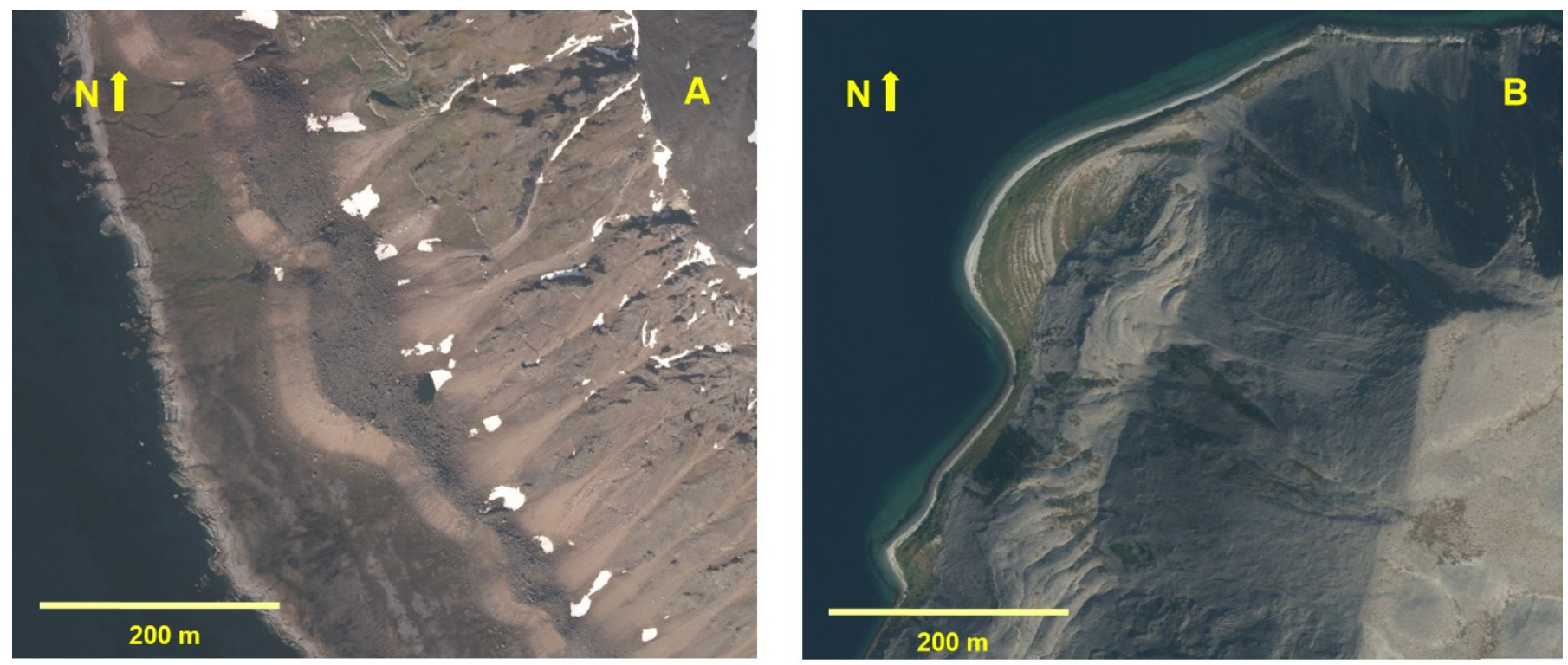

Figure 9 Comparison of landforms in A Svalbard (Prins Karls Forland; Western Spitsbergen; (C) Norwegian Polar Institute) and B Lille Skogfjorden, Finnmark (C) Norwegian Mapping Authorities). In both cases the rock glaciers creep from talus slopes onto the strandflat. Especially in $B$ are the relict shorelines visible.

675 Table 1: Estimated height accuracies of the DEMs used in this study. The year refers to the time the images were collected to produce the DEMs.

\begin{tabular}{lll}
\hline Year & Accuracy $(\mathrm{cm})$ & \\
\hline 1975 & 0.12 & Historical aerial photos \\
1982 & 0.41 & \\
1992 & 0.38 & \\
\hline 2016 & 0.001 & Drone photos \\
2017 & 0.003 & \\
\hline $2017-2020$ & $0.02-0.04$ & TLS \\
\hline
\end{tabular}


Table 2: Vertical and horizontal displacement rates (cm/year) of different pairs of DEMs and orthophotos from Ivarsfjorden rock glacier. TLS: Terrestrial Laser Scans.

\begin{tabular}{|c|c|c|c|c|c|}
\hline \multirow[b]{2}{*}{ Period } & \multicolumn{2}{|c|}{ Vertical displacement } & \multicolumn{3}{|c|}{ Horizontal displacement } \\
\hline & Range (cm yr $\left.{ }^{-1}\right)$ & Mean (cm yr $\left.{ }^{-1}\right)$ & Range (cm yr-1) & Mean (cm yr-1) & \\
\hline $1975-1982$ & $-30-10$ & -10 & $0-2$ & 1 & $\begin{array}{l}\text { Historical } \\
\text { aerial photos }\end{array}$ \\
\hline 1975-1992 & $-10-0$ & -5 & $0-5$ & 1 & \\
\hline $1975-2017$ & $-10-0$ & -7 & $0-3$ & 1 & \\
\hline $1982-1992$ & $-10-20$ & -5 & $0-6$ & 3 & \\
\hline $1982-2017$ & $-7-5$ & -2 & $0-2$ & 1 & \\
\hline $1992-2017$ & $-10-10$ & -3 & $0-2$ & 1 & \\
\hline 2016-2017 & $-10-5$ & 0 & $0-3$ & 2 & Drone photos \\
\hline $2017-2020$ & $-5-2$ & -1 & $0-3$ & 2 & TLS \\
\hline
\end{tabular}

Table 3: Decadal mean air temperatures between 1870 and 2019 from the SeNorge grid cell that covers Ivarsfjorden rock glacier (116 $\mathrm{m}$ a.s.l.) and the neighbouring grid cell to the East which covers the Sandfjellet mountain plateau (338 $\mathrm{m}$ a.s.l.).

\section{MAT $\left({ }^{\circ} \mathrm{C}\right)$}

Rock glacier surface

(SeNorge model elevation

$116 \mathrm{~m}$ a.s.l.)
Plateau East

(SeNorge model elevation $338 \mathrm{~m}$ a.s.I.)
$1870-1879$

1880-1889
$-0.7$

$-0.8$
$-2.0$

$-2.1$ 
https://doi.org/10.5194/esurf-2022-6

Preprint. Discussion started: 3 February 2022

(c) Author(s) 2022. CC BY 4.0 License.

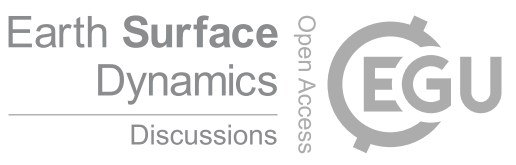

\begin{tabular}{lll}
$1890-1899$ & -0.6 & -1.9 \\
$1900-1999$ & -0.6 & -1.9 \\
$1910-1919$ & -0.7 & -2.0 \\
$1920-1929$ & 0.2 & -1.1 \\
$1930-1939$ & 0.7 & -0.6 \\
$1940-1949$ & -0.1 & -1.3 \\
$1950-1959$ & 0.2 & -1.2 \\
$1960-1969$ & -0.2 & -1.5 \\
$1970-1979$ & 0.1 & -1.1 \\
$1980-1989$ & -0.2 & -1.5 \\
$1990-1999$ & 0.5 & -0.9 \\
$2000-2009$ & 1.2 & 0 \\
$2010-2019$ & 1.6 & 0.4 \\
\hline
\end{tabular}

685

690 